\title{
Anatomical notes and discussion of the first described aetosaur Stagonolepis robertsoni (Archosauria: Suchia) from the Upper Triassic of Europe, and the use of plesiomorphies in aetosaur biochronology
}

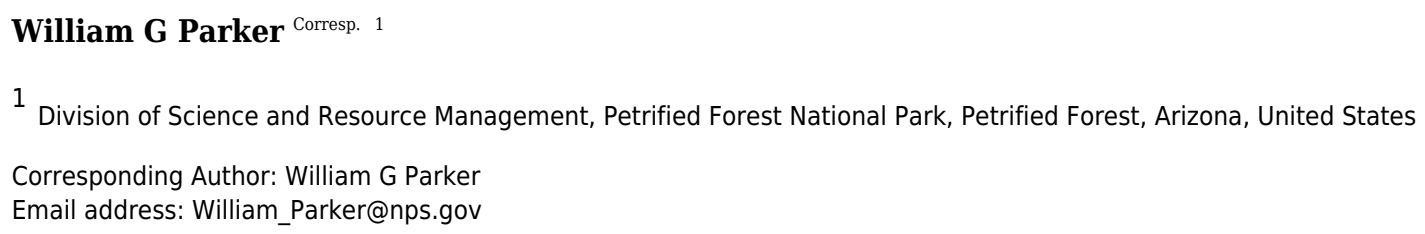

Stagonolepis robertsoni, from the Late Triassic of Scotland, was the first named aetosaurian. Known mostly from a series of natural molds from two localities, the osteology of this taxon has been difficult to interpret. Detailed work on this material in the late 1950s resulted in a monograph that set the standard for the understanding of aetosaurians, making Stagonolepis robertsoni the best known aetosaurian; however, little has been done with this material since. Reanalysis of this material shows that despite its limitations the early 1960s reconstruction work depicts the preserved characteristics faithfully, especially in the skull. The first cervical rib is extremely anteroposteriorly elongate as in Alligator, a character not previously recognized in aetosaurians. Diapophyseal and zygapophyseal vertebral laminae are present in the cervical and trunk vertebrae. The ilium is autapomorphic with distinct pre- and post-processes of the iliac blade. The osteoderms differ from North and South American material that has been ascribed to the genus. Those assignments are based on plesiomorphies within Aetosauria, such as a radial ornamentation and a posteriorly located and medially offset dorsal eminence. Biostratigraphic correlations using taxonomic conclusions based on plesiomorphic characters should not be used. The holotype specimen of $S$. robertsoni is currently diagnostic, in part because ventral osteoderms are not known for many aetosaurian taxa and the surface ornamentation of randomly distributed, closely packed oblong pits found in S. robertsoni is unique within Aetosauria. 
1 Anatomical notes and discussion of the first described aetosaur Stagonolepis robertsoni

2 (Archosauria: Suchia) from the Upper Triassic of Europe, and the use of plesiomorphies in

3 aetosaur biochronology.

4

5 William G. Parker

6 Division of Science and Resource Management, Petrified Forest National Park, Petrified Forest,

7 Arizona 86028

8

9 William_Parker@nps.gov

10

11

12

13

14

15

16

17

18

19

20

21

22

23

24

25

26

27

28 


\section{ABSTRACT}

Stagonolepis robertsoni, from the Late Triassic of Scotland, was the first named aetosaurian. Known mostly from a series of natural molds from two localities, the osteology of this taxon has been difficult to interpret. Detailed work on this material in the late 1950s resulted in a monograph that set the standard for the understanding of aetosaurians, making Stagonolepis robertsoni the best known aetosaurian; however, little has been done with this material since. Reanalysis of this material shows that despite its limitations the early 1960s reconstruction work depicts the preserved characteristics faithfully, especially in the skull. The first cervical rib is extremely anteroposteriorly elongate as in Alligator, a character not previously recognized in aetosaurians. Diapophyseal and zygapophyseal vertebral laminae are present in the cervical and trunk vertebrae. The ilium is autapomorphic with distinct pre- and post-processes of the iliac blade. The osteoderms differ from North and South American material that has been ascribed to the genus. Those assignments are based on plesiomorphies within Aetosauria, such as a radial ornamentation and a posteriorly located and medially offset dorsal eminence. Biostratigraphic correlations using taxonomic conclusions based on plesiomorphic characters should not be used. The holotype specimen of $S$. robertsoni is currently diagnostic, in part because ventral osteoderms are not known for many aetosaurian taxa and the surface ornamentation of randomly distributed, closely packed oblong pits found in S. robertsoni is unique within Aetosauria.

\section{INTRODUCTION}

Aetosaurs are exclusively Late Triassic quadrupedal, heavily armored pseudosuchians known globally with the exception of some parts of Gondwana: southern Africa, Antarctica, and Australia. The most recent overview of this clade is by Desojo et al. (2013), with older material and new taxa recently described by Heckert et al., 2015, Heckert, Fraser \& Schneider 2017, 
53 Parker 2016b, 2018, and Schoch \& Desojo 2016. The first described aetosaurian fossil was

54 christened Stagonolepis robertsoni Agassiz 1844 for a series of ventral osteoderms. Because the

55 unit they were discovered in was thought to be the Devonian 'Old Red Sandstone', these

56 osteoderms were considered to represent a large ganoid fish (Agassiz 1844). Subsequent

57 discoveries (detailed in Walker 1961) demonstrated that these remains belonged instead to a

58 stem-crocodylian, and that the rocks they were found in were instead more likely Triassic in age

59 (Huxley 1859, 1869; 1875; 1877). The original materials worked on by Louis Agassiz and T.H.

60 Huxley, as well as additional discoveries made in the 1920s and 1930s, were the subject of an

61 extensive monograph (Walker 1961). This work was influential because it finally established that

62 aetosaurians were a globally distributed Late Triassic group distinct from phytosaurs.

63 Although since that time the only new material described for Stagonolepis robertsoni is a

64 braincase (MCZD 2-4; Gower \& Walker 2002), S. robertsoni is still considered to be the 'model'

65 aetosaurian (Desojo et al. 2013) and the taxon is featured prominently in phylogenetic and

66 biomechanical analyses (e.g., Parrish 1994; Heckert, Hunt, \& Lucas 1996; Heckert \& Lucas

67 1999; Parker 2007; Desojo \& Vizcaíno 2009; Parker 2016a). However, since 1961 the taxon has

68 never been adequately re-evaluated despite the great strides that have been made in our

69 understanding of aetosaurian morphology and systematics, particularly the recognition that

70 armor surface ornament, width-length ratios, and lateral osteoderm morphology are diagnostic to

71 clades, and in some cases, to species (e.g., Long \& Ballew 1985; Long \& Murry 1995; Heckert

72 \& Lucas 2000; Parker 2007; Martz \& Small 2006). Other named taxa (Calyptosuchus wellesi

73 Long \& Ballew 1985, Ebrachosaurus singularis Kuhn 1936, Aetosauroides scagliai

74 Casamiquela 1960; Argentinosuchus bonapartei Casamiquela 1960) have been assigned to the

75 genus Stagonolepis based on the presence of a radial dorsal paramedian osteoderm 
ornamentation and a width/length ratio of 2.5/1 (e.g., Long and Murry, 1995; Heckert \& Lucas 2000, 2002); however, these assignments have been questioned or refuted by other workers (e.g., Desojo \& Ezcurra 2011; Parker 2018). A closely related species, Stagonolepis olenkae Sulej 2010, has been described from Poland and its distinctness from S. robertsoni is debated (Lucas, Spielmann \& Hunt 2007; Antczak 2016); however, it is treated here as distinct as discussed by Parker (2016a).

The purpose of this paper is to reanalyze referred material of Stagonolepis robertsoni present at the Natural History Museum, London and evaluate it in context of on our current understanding of aetosaurian anatomy. The material is not fully redescribed here as the original descriptions by Walker (1961) and Gower \& Walker (2002) are still quite adequate; instead we focus on characteristics whose taxonomic significance was not completely recognized by Walker given the understanding of aetosaurians at the time of his monograph. These newly recognized characteristics are useful for examining the phylogenetic relationships of S. robertsoni and other aetosaurians and further demonstrates the importance of redescribing original historic type specimens (Parker 2013).

\section{MATERIALS}

Of the materials of Stagonolepis robertsoni that were available to Huxley $(1859,1875$, 1877) those available today at the Natural History Museum, London consist only of a couple of now chipped casts of a left femur (NHMUK PV R 581) and a paramedian osteoderm and phalanx (NHMUK PV R 582). The rest of the material is in other institutions such as the

7 Geological Survey Museum, Keyworth and the Elgin Museum in Scotland (Walker 1961;

Walker undated and unpublished notes at the NHMUK). More prominent materials at the

99 NHMUK consist almost entirely of large blocks of a highly indurated sandstone that preserve 
100

101

102

103

104

105

106

107

108

109

110

111

112

113

114

115

116

117

118

119

120

121

122

natural molds of various bones. Painted casts of these were created in 1885 and presented to the museum by the Reverend George Gordon. These specimens allow study of portions of the bones in two dimensions, and were available for study to Charles Camp in 1935 (Camp unpublished notes at the UCMP, 1935) and Alick Walker in the 1950s (Walker 1961). Walker (1961) also created a series of PVC casts (e.g., NHMUK PV R4787) from the original sandstone molds that preserved more detail and allowed for 3D visualization of the bones. These PVC casts are still in the NHMUK collections although many have deteriorated significantly.

For this study the following blocks/specimens were examined and photographed:

MCZD2 (5 parts), partial skull and articulated cervical osteoderms; NHMUK PV R 581, cast of a left femur; NHMUK PV R 582, cast of a paramedian osteoderm and a phalanx; NHMUK PV R 4784a, cast of a slab with a basioccipital and associated articulated series of cervical and trunk vertebrae, including the cervical ribs, scapulocoracoid, partial humerus; NHMUK PV R 4785a, cast of a slab with osteoderms and ribs; NHMUK PV R 4786a, cast of a slab with anterior caudal centra and ribs in articulation, and the distal end of a left tibia; NHMUK PV R 4787; sandstone block containing the natural mold of much of a skull plus an associated PVC cast; NHMUK PV R 4787a, a cast of a specimen showing the lower portion of the left side of a good skull, especially the mandible; NHMUK PV R 4789a, cast of a slab with ribs, osteoderms, a right ilium, and a partial maxilla; NHMUK PV R 4790a, cast of a slab with osteoderms, a right ilium, and an ischium; NHMUK PV R 4797a, a cast with lower limb bones and appendicular osteoderms; NHMUK PV R 4799, a sandstone block with an impression of an anterior cervical vertebra; NHMUK PV R 8586, a cast of ELGNM 38R, the left side of internal surface of snout (figured by Huxley, 1877); NHMUK PV R 27404, a cast of the holotype specimen that consists of a segment of the articulated ventral carapace; NHMUK PV R 36392, a sandstone slab with 
123 osteoderms, including six articulated left lateral osteoderms; NHMUK PV R 36394; a sandstone

124 slab with the impressions of articulated ventral osteoderms.

An attempt was made to use the CT scanner at the NHMUK to scan the negative space in

126

127

128

129

130

131

132

133

134

135

136

137

138

139

140

141

142

143

144

145

SYSTEMATIC PALEONTOLOGY

Archosauria Cope, 1869 sensu Gauthier \& Padian, 1985

Pseudosuchia Zittel, 1887-1890 sensu Gauthier \& Padian, 1985

Aetosauria Marsh, 1884 sensu Parker, 2007

Desmatosuchia sensu Parker, 2016a

Stagonolepidinae sensu Heckert \& Lucas, 2000

Stagonolepis Agassiz, 1844

Stagonolepis robertsoni Agassiz, 1844

1844 Stagonolepis robertsoni: Agassiz, p. 139, pl. XXXI, figs. xiii, xiv

1859 Stagonolepis robertsoni: Huxley, p. 440, pl. XIV, figs. 1-3

1877 Stagonolepis robertsoni: Huxley, p. 1, pl. I-X.

1902 Staganolepis [sic] robertsoni: Huene, p. 54, figs. 62-67, 72, 73.

1908 Stagonolepis robertsoni: Huene, p. 392, figs. 347-348.

1936 Stagonolepis robertsoni: Huene, p. 207, fig. 3.

1942 Stagonolepis robertsoni: Huene, p. 223, figs. 45-49.

1961 Stagonolepis robertsoni: Walker, p. 103, figs. 2-23, 24b, 25b, pl. 9-12. 
1461976 Stagonolepis robertsoni: Krebs, p. 40, figs. 3, 4, 9, 10d, 12, 15, 16, 17c-e, 19d-e, 147 20d-e, 26b, 27.

1481978 Staganolepis [sic]: Bonaparte, p. 300, figs. 137b, 138.

1491986 Stagonolepis: Parrish, p. 8, fig. 6, 14c3.

1501988 Stagonolepis: Carroll, p. 273, figs. 13.15, 13.16.

1511988 Stagonolepis: Fraser, p. 132, fig. 5b.

1521991 Stagonolepis: Sereno, p. 11, fig. 10, 27 f.

1531996 Stagonolepis: Lucas \& Heckert, p. 57, fig. 4.

1542000 Stagonolepis robertsoni: Heckert \& Lucas, 2000, p. 1552, figs. 4c, e.

1552001 Stagonolepis robertsoni: Lucas \& Heckert, p. 719, figs. 2, 3.

1562002 Stagonolepis robertsoni: Gower \& Walker, p. 7, figs. 1-4, 6.

1572010 Stagonolepis robertsoni: Sulej, p. 878, figs. 8a, 9f.

1582011 Stagonolepis robertsoni: Desojo \& Ezcurra, p. 599, figs. 3d-f, 7b.

1592013 Stagonolepis robertsoni: Desojo et al., p. 207, figs. 3e-f, 4g, 5a-h, 6a-f, 7c-f.

160 2016a Stagonolepis robertsoni: Parker, p. 32, figs. 1, app. B, fig. 11j.

161

162

163

164

165

166

167

168

Holotype - ELGNM 27R, impression of a segment of the ventral carapace (Agassiz

1844). NHMUK PV R 27404 is a negative cast of this specimen.

Referred Material - see Materials for a list of NHMUK specimens.

Occurrence - Lossiemouth Sandstone Formation, Moray, Scotland, U.K (Walker 1961).

$\boldsymbol{A g} \boldsymbol{e}$ - Late Triassic, late Carnian to early Norian (Benton \& Walker 2011).

Diagnosis - Stagonolepis robertsoni is diagnosed by the following autapomorphies:

ventral osteoderms rectangular with randomly arranged, oblong pits; first cervical vertebra with 
169 elongate cervical ribs that extend back to the position of the $4^{\text {th }}$ cervical vertebra; posterior

170 process of iliac blade forms an acute angled tip; anterior process of the iliac blade is

171 anteroposteriorly short, dorsoventrally thin, and ventrally hooked.

172 Stagonolepis robertsoni can also be distinguished by the following combination of

173 character states: premaxilla with four, possibly five teeth as in Stagonolepis olenkae and

174 Paratypothorax andressorum Long \& Ballew 1985, Aetosaurus ferratus Fraas 1877, and

175 Neoaetosauroides engaeus Bonaparte 1978 (differs from three in Stenomyti huangae Small \&

176 Martz 2013, and the absence of premaxillary teeth in Desmatosuchus smalli Parker 2005);

177 premaxillary tip expanded laterally as in Stagonolepis olenkae, Desmatosuchus smalli, and

178 Neoaetosauroides engaeus (absent in Aetosaurus ferratus, Stenomyti huangae; Paratypothorax

179 andressorum); distinct ridge on lateral side of maxilla beneath the antorbital fossa as in

180 Paratypothorax andressorum and Stenomyti huangae (this ridge is absent in Desmatosuchus

181 smalli, Longosuchus meadei Sawin 1947, Neoaetosauroides engaeus, and Stagonolepis olenkae);

182 long axis of the jugal anterodorsally inclined as in Desmatosuchus spurensis Case 1920 and

183 Longosuchus meadei (the ventral margin of the jugal is level in Aetosaurus ferratus,

184 Paratypothorax andressorum, and Stenomyti huangae); teeth thecodont with a swollen bases and

185 non-recurved tips as in Desmatosuchus smalli (differs from Aetosauroides scagliai and

186 Aetosaurus ferratus); parabasisphenoid elongate, with anteroposteriorly separated basal tubera

187 and basipterygoid processes as in Neoaetosauroides engaeus, Aetosaurus ferratus, and

188 Desmatosuchus smalli (differs from Scutarx deltatylus Parker 2016a, Paratypothorax

189 andressorum, Tecovasuchus chatterjeei Martz \& Small 2006, and Desmatosuchus spurensis);

190 mandible "slipper-shaped" with ventrolateral portion of the splenial visible in lateral view

191 beneath the ventral margin of the dentary as in all aetosaurs except for Aetosauroides scagliai 
192 and Typothorax coccinarum Cope 1875; posterior cervical vertebrae with a ventral keel as in

193 Aetosauroides scagliai, Calyptosuchus wellesi, Sierritasuchus macalpini Parker, Stocker \& Irmis

194 2008, Neoaetosauroides scagliai, and Scutarx deltatylus (keels absent in Longosuchus meadei,

195 Desmatosuchus spurensis, and Aetobarbakinoides brasiliensis Desojo, Ezcurra \& Kischlat

196 2012); pubis with two obturator foraminae (convergent in Scutarx deltatylus); trunk and anterior

197 caudal paramedian osteoderms with a length/width ratio of about 2.5:1 as in Desmatosuchus

198 spurensis, Longosuchus meadei, and Aetobarbakinoides brasiliensis (differs from the much

199 wider paramedians of Typothorax coccinarum and Paratypothorax andressorum); raised anterior

200 bar on osteoderms as in all non-desmatosuchin (sensu Parker 2016a) aetosaurs; anteromedial and

201 anterolateral projections of the anterior bar present on the trunk osteoderms as in all non-

202 desmatosuchin aetosaurs; anterolateral projection of the anterior bar not elongate as in

203 Stagonolepis olenkae, Aetosaurus ferratus, and Typothorax coccinarum (differs from

204 Adamanasuchus eisenhardtae Lucas, Hunt \& Spielmann 2007 and Scutarx deltatylus); trunk

205 paramedian osteoderms lack ornament along the posterior edge in the region of the dorsal

206 eminence as in Aetosauroides scagliai; dorsal eminence of trunk paramedian osteoderms situated

207 on the posterior osteoderm margin and offset medially (as in most aetosaurs except

208 Desmatosuchus and Paratypothorax andressorum); dorsal surface ornament of the paramedian

209 and lateral osteoderms anastomosing (interconnected series of radiating ridges surrounding

210 subrounded and subrectangular pits, Taborda, Heckert \& Desojo 2015); lateral osteoderms are

211 nearly equant with distinct lateral and dorsal flanges as in all non-desmatosuchin aetosaurs;

212 lateral osteoderms lack pronounced horns or spines as in most aetosaurs outside of

213 Typothoracisinae and Desmatosuchini. 


\section{Skull}

216 Block NHMUK PV R 4787a is a cast of the lower portion of a skull in semi-articulation

217 including much of the lower jaw, quadrate, portions of the palate and maxilla, and the premaxilla

218 (Figure 1A). These elements represent the left side of the skull, so the cast provides an internal

219 (medial) view. The semi-articulated condition allows for the determination of the skull length,

220 which from the retroarticular process to the tip of the premaxilla is about $240 \mathrm{~mm}$. The

221 dentigerous elements show the presence of at least eight dentary, four maxillary, and four

222 premaxillary teeth. Alick Walker's PVC cast of this specimen shows even more details (Figure

223 1B) including the upper portions of the skull and the braincase, especially the parabasisphenoid.

224 Thus block NHMUK PV R 4787 is the natural mold of a nearly complete skull of Stagonolepis

225 robertsoni (Walker 1961). Details of this specimen that are not visible in the cast NHMUK PV R

226 4787a include: 1) a possible $5^{\text {th }}$ premaxillary tooth crown, or alternatively the tip of the right

227 premaxilla in articulation with the left (Figure 1b);2) a portion of the right squamosal and

228 impressions of the skull roof, 3) the left quadrate in articulation with the left articular, and 4)

229 impressions of the braincase, especially the basisphenoid including the left and right basitubera

230 and basipterygoid processes, and the cultriform process is also preserved.

231

A cast of the right maxilla from NHMUK PV R 4787 (Figure 2) shows that overall the

232 element is more slender than that of Stagonolepis olenkae (Sulej 2010) with at least six alveoli

233 (Figure 2b), but the anterior portion is covered. A very distinct transverse ridge is present on the

234 lateral surface along the anterior and ventral borders of the antorbital fossa, making the fossa

235 extremely pronounced; this ridge also occurs in Stenomyti huangae (Small and Martz, 2013) and

236 Paratypothorax andressorum (Schoch and Desojo, 2016), but is not present in Stagonolepis

237 olenkae (Sulej 2010), Desmatosuchus (Case, 1922; Small, 2002), Longosuchus (Parrish, 1994), 
238 or Neoaetosauroides (Desojo and Báez, 2007). The medial side of the maxillary body is marked

239 by an elongate medial shelf that articulates with the palatal bones (Walker 1961). The

240 articulations with the lacrimal and jugal are each complex, with regions of overlap between the

241 two bones; this is also visible in Longosuchus meadei (TMM 31185-98), Stagonolepis olenkae

242 (ZPAL AbIII/2454/3), and Aetosauroides scagliai (USFM 11050), and probably present in other

243 aetosaurs as well but obscured in most articulated skulls. Finally, a pneumatic accessory cavity is

244 present on the medial size of the ascending process as described for Desmatosuchus smalli

245 (Small 2002).

NHMUK PV R 8586 is a cast of ELGNM 38R (Figure 3), which was figured by Huxley

247 (1877) and features the left side of the internal portion of the snout, including the premaxilla,

248 maxilla, and nasals. The premaxilla measures $63 \mathrm{~mm}$ in length and bears four teeth (Figure 3)

249 with an edentulous anterior portion typical for aetosaurians; four or more teeth also occur in

250 Aetosaurus ferratus (Schoch, 2007) Stagonolepis olenkae (Sulej, 2010), Neoaetosauroides

251 engaeus (Desojo and Báez, 2007), and Paratypothorax andressorum (Schoch and Desojo, 2016),

252 whereas Stenomyti huangae only possesses three (Small and Martz, 2013), and Desmatosuchus

253 lacks any (Small, 2002). The maxilla bears six teeth as preserved, but it is missing the posterior

254 portion. The external naris is $22 \mathrm{~mm}$ at its deepest point and $72 \mathrm{~mm}$ in length, but missing the

255 posteriormost section. The nasal has a pronounced ridge on the medial edge, which at a position

256 just dorsal to the $3^{\text {rd }}$ premaxillary tooth migrates ventrally to the ventral margin of the nasal

257 where it contacts the premaxilla. The anterior tip of the premaxilla bears a prominent ridge that

258 divides the element into a flat surface that slopes into the external naris, and a second triangular

259 area that slopes anteroventrally (Figure 3). This ridge is the anterior expansion and also occurs in

260 other aetosaurians such as Desmatosuchus smalli (Small 2002), Neoaetosauroides engaeus (PVL 
261 4363), and differs from aetosaurians such as Aetosaurus ferratus (Schoch 2007), Aetosauroides

262 scagliai (PVL 2059), and Typothorax coccinarum (YPM 58121). The premaxilla bears a small

263 dorsal protuberance above the first tooth position that extends dorsally into the external naris

264 (Walker, 1961), which also occurs in Stagonolepis olenkae (Sulej 2010) and Desmatosuchus

265 smalli (Small 2002); however, in S. olenkae it is dorsal to the second tooth position (Antczak

266 2016) and D. smalli has an edentulous premaxilla (Small 2002). There is only a slight swelling in

267 this position in Stenomyti huangae (Small and Martz, 2013).

268 The best-preserved skull material is MCZD 2, which consists of seven small blocks that

269 fit together to present much of the skull and the anterior section of the neck (Walker 1961:figs.

270 26-29; Gower \& Walker 2002:fig. 1). The material consists of well-preserved bone and is not a

271 natural mold as is most of the $S$. robertsoni material. This specimen has previously been

272 described in great detail so this will not be duplicated here (Walker 1961; Gower \& Walker

273 2002). However, notable is that the basitubera and basipterygoid processes are widely separated

274 anteroposteriorly from each other so that the parabasisphenoid is elongate, supporting what can

275 be observed in NHMUK PV R 4787. Neoaetosauroides engaeus (PVL 5698; Desojo \& Báez

276 2007), Aetosaurus ferratus (Schoch 2007), Paratypothorax andressorum (Schoch and Desojo,

277 2016), and the basal taxon Aetosauroides scagliai (PVSJ 326) also have an elongate

278 parabasisphenoid, so that is the plesiomorphic state within Aetosauria. This differs significantly

279 from the condition in S. olenkae, where the basitubera and basipterygoid processes nearly contact

280 (Sulej, 2010: figs. 1d, f) and thus the parabasisphenoid is anteroposteriorly short. In Scutarx

281 deltatylus (Parker, 2016b: fig. 7) and Desmatosuchus spurensis (UMMP 7476) the

282 parabasisphenoid is also anteroposteriorly short; whereas the condition in Calyptosuchus wellesi

283 is unknown (Parker 2018). 


\section{Presacral vertebrae and ribs}

286

287

288

289

290

291

292

293

294

295

296

297

298

299

300

301

302

303

304

305

306

In block NHMUK PV R 4784a, which is a cast created from a natural mold and represents the postcranial skeleton of the skull NHMUK PV R 4787 (Walker 1961), the occipital condyle and left paroccipital process of the skull are present (Figure 4A). If the cervical count is nine (as in Desmatosuchus spurensis), the four anterior cervicals are missing (including the axis and atlas); however, cervical ribs are present for three of these positions. Especially striking are two very elongate posteriorly projecting cervical ribs underlying the ventral surfaces of the two more posteriorly positioned ribs (Figure 4A). The elongate ribs (left and right sides) originate where the axis/atlas would be located and are very similar to the greatly elongate cervical ribs found in Alligator (Reese 1915). As exposed these ribs measure 85mm in length (the ends are covered), more than three times the lengths of the other exposed cervical ribs. The elongate ribs were not noted by Walker (1961) and have not previously been described for any aetosaur. The axis/atlas and third cervical are present in MCZD 2, but unfortunately are very poorly preserved; however, this block also preserves a very elongate first cervical rib.

The first well-preserved cervical vertebra in NHMUK PV R 4784a is the $8^{\text {th }}$ (Walker 1961), which is visible in right lateral view and preserves details of the centrum and much of the neural arch and transverse process (Figure 4B). A disarticulated cervical rib is present across the centrum and probably does not belong to this vertebra. The centrum measures $25 \mathrm{~mm}$ in length and the ventral surface is strongly keeled. Keels occur on the ventral surfaces of the cervical vertebrae in Aetosauroides (Desojo and Ezcurra, 2011), Neoaetosauroides (Desojo and Báez, 2007), and Scutarx (Parker 2016) while the ventral surfaces of the cervicals lack keels in Longosuchus (Long and Murry, 1995) and Desmatosuchus (Case, 1922; Parker, 2018), and 
307 Aetobarbakinoides (Desojo, Ezcurra, and Kischlat, 2012). The condition may be variable in

308 Typothorax; ventral keels are absent in the cervicals of the small specimen described by Martz

309 (2002) but present in at least some larger specimens (Heckert et al., 2010), suggesting there may

310 be allometric or ontogenetic variability. The parapophysis in the $8^{\text {th }}$ cervical of NHMUK PV R

$3114784 \mathrm{a}$ is low on the anterior rim of the centrum, but not completely at the base. The transverse

312 process projects laterally and slightly ventrally, is $25 \mathrm{~mm}$ long, and bears a flaring sub-

313 rectangular head in lateral view. A distinct posterior centrodiapophyseal lamina (Wilson 1999)

314 stretches from the base of the transverse process to the posterior portion of the neurocentral

315 suture. This is the "T-beam" structure described by Case (1922) for the posterior cervical and

316 dorsal vertebrae of Desmatosuchus spurensis and described as present in Stagonolepis robertsoni

317 (Walker, 1961) and Typothorax (Martz, 2002) and also occurs in Paratypothorax (Martz et al.,

318 2013, fig. 9D). The right prezygapophysis is present but not enough is present to tell if a

319 hyposphene was present. The neural spine is present, but missing the apex.

320 The next three vertebrae are preserved in articulation (Figure 4B). The parapophysis on

321 the $9^{\text {th }}$ cervical is still situated on the centrum, but slightly higher than its position in the

322 preceding vertebra. The centrum is more elongate as well, measuring $31 \mathrm{~mm}$. Pre- and

323 postzygadiapophyseal laminae (Wilson 1999) are visible on the $9^{\text {th }}$ and $10^{\text {th }}$ presacrals (Figure

324 4B). The $10^{\text {th }}$ presacral is transitional between the cervical and dorsal series as previously

325 described for Desmatosuchus spurensis (Case 1922; Parker 2008). The centrum is more elongate

326 than the previous vertebra with a length of $36 \mathrm{~mm}$. However, there is still a slight ventral keel as

327 in the other cervicals, and although the parapophysis has migrated upwards onto the base of the

328 neural arch, it is not located on the arch itself as in the trunk vertebrae. The neurocentral suture

329 appears to be open. 
situated on the posteroventral surface of the transverse process. Unfortunately this cannot be seen clearly as it is broken away (Walker 1961:fig. 7i). The centrum has a length of $39 \mathrm{~mm}$ and is unkeeled. The $12^{\text {th }}$ presacral is present, but covered by broken ribs. The cervical and trunk vertebrae of $S$. robertsoni lack oval depressions on the lateral sides just below the neurocentral sutures as in Aetosauroides scagliai (Desojo \& Ezcurra 2011).

\section{Caudal Vertebrae}

NHMUK PV R 4799b is a PVC cast of an isolated anterior caudal vertebra providing more details of the neural arch and spine (Walker 1961: figs. 10c-e). The broad transverse processes (left equals $79 \mathrm{~mm}$ ) do not extend ventral to the base of the centrum; the postzygapophyses are oriented at 45 degrees above horizontal. The centrum is blocky, with equant width and height of about $40 \mathrm{~mm}$, but the entire vertebral height is $112 \mathrm{~mm}$, with the neural spine contributing 40 $\mathrm{mm}$ to this measurement. Spinopostzygapophyseal laminae (Wilson 1999) are present, as is the expanded neural spine table.

\section{Osteoderms} considered superficial terms, therefore one each of the best preserved dorsal paramedian and lateral osteoderms is redescribed determining estimated position using the technique presented by Parker and Martz (2010). The dorsal paramedian osteoderm (NHMUK PV R 4790a; Figure $5 \mathrm{~A}$ ) is from the left side, has a width/length ratio of $2.4 / 1$, and an anastomosing surface patterning (Taborda, Heckert, and Desojo 2015), an anastomosing, interlaced network of high 
354 ridges surrounding circular and elongate pits closer to the posterior plate margin, and elongate,

355 but irregular grooves on the anterior portion of the osteoderm. The width/length ratio, the slight

356 ventral flexion, and the more medially situated position of the dorsal eminence suggests that this

357 osteoderm is from the anterior caudal region based on comparison with the holotype specimen of

358 Calyptosuchus wellesi (Case, 1932) and a referred specimen of Aetosauroides scagliai (MCP

359 13a-b-PV). The ornamentation is similar to the pattern in Aetosaurus ferratus, Aetosauroides

360 scagliai, Neoaetosauroides engaeus, "Stagonolepis" olenkae, and Paratypothorax andressorum

361 in that the ornamentation is non-radial posteromedially, but elongate and radial anteriorly along

362 the full length of the anterior bar. However, in S. robertsoni, the ornamentation on the

363 posterolateral region of the paramedians is distinctly non-radial and faint to absent along the

364 entire posterior margin, whereas in the other taxa the paramedians possess very elongate grooves

365 in the posterolateral portion of the paramedian osteoderm that are nearly parallel to the posterior

366 margin.

367 This anastomosing ornamentation in S. robertsoni radiates from an elongate, but narrow,

368 raised dorsal eminence that contacts the posterior osteoderm margin as in most non-

369 desmatosuchine taxa that possess an eminence; in desmatosuchines, the eminence often contacts

370 the posterior margin (Parker, 2018; Parker and Martz, 2010). This eminence is rounded rather

371 than distinctly pyramidal as in Typothorax (Martz, 2002) and Longosuchus (Parker and Martz,

372 2010), and offset medially from the center of the osteoderm as in nearly all aetosaurian posterior

373 trunk and anterior caudal paramedians. The anterior portion of the osteoderm bears a raised,

374 transverse, smooth strip of bone called the anterior bar (Long \& Ballew 1985) that bears

375 anterolateral and anteromedial projections as in most non-desmatosuchine aetosaurs. The

376 anterior bar maintains an even width across the lateral portion of the osteoderm, but thins 
377 significantly medially before expanding again at the anteromedial projection. This distinct

378 medial thinning is termed 'scalloping' (following Parker, 2016b). This feature occurs in several

379 other aetosaurians including Aetosauroides scagliai (PVL 2073), Calyptosuchus wellesi (UCMP

380 126844; Parker 2018), Scutarx deltatylus (Parker 2016b), and Paratypothorax andressorum

381 (SMNS 5721). The medial edge is straight and the lateral edge slightly sinuous in dorsal view. In

382 posterior view the osteoderm is moderately flexed.

The lateral trunk osteoderm (NHMUK PV R 4789a; Figure 5B) is from the right side

based on the presence of a distinct beveling of the anteromedial corner of the anterior bar, which

represents an articulation surface for the anterolateral process of the adjacent paramedian

osteoderm. The bar is thin but stretches across the entire anterior margin of the osteoderm. The

osteoderm is trapezoidal in dorsolateral view and a ridge-like dorsal eminence that contacts the

is roughly trapezoidal in dorsal view, whereas the lateral flange is slightly larger and sub-

rectangular in dorsolateral view. The surface ornamentation is anastomosing and very faint in the

posterior portion of the osteoderm, as seen in the paramedian. The osteoderm is slightly flexed ventrally and the angle between the two flanges is obtuse. In dorsolateral view the lateral margin the adjacent paramedian osteoderm.

NHMUK PV R 4789a; Figure 6A, B) are rectangular, bear an anterior bar, and possess an ornamentation of randomly arranged oblong pits, the 'drops' which Agassiz (1844) used to 
400

401

402

403

404

405

406

407

408

409 410 (Small \& Martz 2013).

411

412

413

414

415

416

417

418

419

420

421

422

\section{Ilium}

Typothorax coccinarum (Martz, 2002; Heckert et al. 2010). These taxa also have rectangular ventral osteoderms, but the ornamentation arrangement is more radial and consists of very elongate furrows and ridges, even in Typothorax, where paramedian osteoderm ornamentation is distinctly pitted. Coahomasuchus kahleorum Heckert \& Lucas 1999 and Aetosaurus ferratus (Schoch 2007) preserve more equant, overlapping ventral osteoderms; but the surface ornament on these specimens is poorly preserved and difficult to comprehend. Where they are preserved, however, they appear to consist of finer pits, less densely packed, but nonetheless have a strong radial distribution as in Coahomasuchus chathamensis Heckert, Fraser \& Schneider 2017 and the previous taxa. The ventral osteoderms of S. robertsoni also differ from Stenomyti huangae where the osteoderms are subrounded rather than square and broadly separated rather than overlapping

Described in detail by Walker (1961), the ilium of Stagonolepis robertsoni is autapomorphic. The shapes and sizes of the processes of the iliac blade are particularly diagnostic for aetosaurian taxa. S. robertsoni possesses an elongate postacetabular blade that ends in an acute angled end in medial view (Figure 7). Most other aetosaurians have a squaredoff end of the postacetabular blade such as Aetosauroides scagliai (PVSJ 326; PVL 2073), Calyptosuchus wellesi (UCMP 32422), Longosuchus meadei (TMM 31185-40) and Neoaetosauroides engaeus (PVL 3525). Typothorax coccinarum (UMCP 35255) has a postacetabular blade that has a squared off end and is very short, barely extending past the posterior edge of the ischiadic peduncle.

The preacetabular blade of $S$. robertsoni differs from almost all aetosaurians in that it is very anteroposteriorly short in that it does not extend to the anterior margin of the pubic 
423 peduncle, very narrow, and ventrally hooked (Figure 7). Most aetosaurians have preacetabular

424 blades that extend anteriorly to the edge of the pubic peduncle, and are thick and triangular in

425 lateral view, such as Aetosauroides scagliai (PVL 2073), Desmatosuchus spurensis (UMMP

426 7476), and Calyptosuchus wellesi (UCMP 32422). Neoaetosauroides engaeus (PVL 3525) and

427 Typothorax coccinarum (UCMP 35255) both have thin preacetabular blades and the element in

$428 T$. coccinarum is very strongly hooked ventrally; however, in both taxa the preacetabular blades

429 are much more elongate than in $S$. robertsoni, even extending past the anterior margin of the 430 pubic peduncle.

Two ilia similar to that of $S$. robertsoni are TMM-31100-1 and UMMP 7322. TMM-

31100-1, assigned to Lucasuchus hunti Long \& Murry 1995, has the elongate and acute angled

433 tip of the postacetabular blade, as well as a narrower and slightly ventrally hooked preacetabular

434 blade; however, the preacetabular blade is more anteroposteriorly elongate than that of $S$.

435 robertsoni extending to the margin of the pubic peduncle. UMMP 7322, referred to

436 Desmatosuchus spurensis by Long \& Murry (1995), also has an acutely angled postacetabular

437 blade end and a relatively narrow and slightly ventrally hooked preacetabular blade, but again

438 the preacetabular blade is more elongate, in this case extending slightly anterior to the anterior

439 margin of the public peduncle.

440 Overall the ilium most resembles that of Aetosaurus ferratus (Schoch, 2007) with a

441 short, narrow and ventrally hooked preacetabular blade, but the posterior acetabular blade end is

442 not as acutely angled in medial view.

443 Pubis

An odd characteristic of the pubis of Stagonolepis robertsoni is the presence of two large pubic foramina, the uppermost of which represents the obturator foramen (Walker 1961). This 
446 was unique until the discovery of the same feature in the pubis of Scutarx deltatylus (Parker

447 2016b). The pubis is poorly known in many aetosaurs; however, Desmatosuchus spurensis

448 (MNA V9300) has only a single opening.

449

450

\section{PHYLOGENY}

The most inclusive recent phylogenetic analysis of the Aetosauria is that of Parker

452 (2016a). That study is the only analysis to include both species of Stagonolepis (S. robertsoni; $S$.

453 olenkae), and tests the relationships of other species that have historically been considered to

454 belong to Stagonolepis (Calyptosuchus wellesi; Aetosauroides scagliai) (Heckert \& Lucas 1999,

455 2000, 2002). That analysis analyzed relationships between 26 in-group taxa utilizing 83

456 characters (Parker 2016a). Stagonolepis robertsoni is recovered in a clade (Stagonolepidinae

457 with Polesinesuchus aurelioi Roberta-da-Silva et al 2014) within Desmatosuchia and as the sister

taxon to Desmatosuchinae (Figure 8). Stagonolepis olenkae and Calyptosuchus wellesi are

recovered within Desmatosuchinae, whereas Aetosauroides scagliai is recovered outside of

460 Stagonolepididae, as in other recent studies (Desojo et al. 2012; Heckert et al. 2015).

Polesinosuchus forming a sister clade to $S$. olenkae and all other desmatosuchines. The previous 2010; Antczak 2016; Parker 2016a); however, many sections of the published description of the skull of S. olenkae (Sulej 2010) are nearly verbatim to those published by Walker (1961) for $S$.

466 robertsoni, so it is difficult to determine what material is actually being described in the Sulej 467 paper. 
Antczak (2016) used newly referred material from the Krasiejów quarry to hypothesize

469

470

471

472

473

474

475

476

477

478

479

480

481

482

483

484

485

486

487

488

489

490

that that the two taxa may be conspecific, with some of the cranial differences between $S$.

robertsoni and $S$. olenkae representing individual variation. Further support for this hypothesis

was cited by Antczak (2016) as coming from the postcranial analysis of S. olenkae by Lucas,

Spielmann and Hunt (2007) who also argued that $S$. olenkae was a synonym of S. robertsoni.

However, this synonymy is based on plesiomorphies and not a detailed determination of apomorphies in the material. Moreover, the findings of Antczak (2016) suggest that the skull roof (ZPAL AbIII/466/17) proposed by Sulej (2010) may not serve adequately as a holotype for S. olenkae, making comparisons between the two taxa problematic.

Comparison of the paramedian osteoderms of the two taxa demonstrate that although both have similar width/length ratios, and anterior bars, and radial patterning, the patterning is quite distinct with that of $S$. olenkae consisting of more closely packed elongate ridges and grooves (Figure 9). Nonetheless, this comparison is based on a single published osteoderm of $S$. olenkae (Lucas, Spielmann \& Hunt 2007:fig. 4a) and more osteoderm material is needed to further support any proposed differences. Thus, a full description of the postcrania and osteoderms of $S$. olenkae is required to further examine potential differences between these two species.

Another recent phylogenetic analysis (Figure 10; Hoffman, Heckert \& Zanno 2018) of the Aetosauria that also builds on successive analyses from Heckert \& Lucas (1999), Parker (2007), Desojo, Ezcurra \& Kischlat (2012), Heckert et al (2015), and Schoch \& Desojo (2016), but does not include all currently known taxa (e.g., Stagonolepis olenkae) also recovers $S$. robertsoni in Stagonolepidinae as the sister taxon to Desmatosuchinae (=Desmatosuchini of Parker 2016a). Interestingly, with the exclusion of $S$. olenkae from the analysis, the sister taxon 
491 to S. robertsoni is Calyptosuchus (Stagonolepis) wellesi. Thus presently there is strong

492 agreement between the phylogenetic position of $S$. robertsoni in these studies as more closely

493 related to Desmatosuchinae than to Typothoracinae (Figures 7, 9; Parker 2016a; Hoffman,

494 Heckert \& Zanno 2018).

\section{DISCUSSION}

496 Use of symplesiomorphies in aetosaurian taxonomy

497 The first formal diagnosis of Stagonolepis robertsoni (Heckert \& Lucas 2000:1556) was

498 based on plesiomorphies that do not even comprise a unique combination of characters within

499 Aetosauria and was intended to only diagnose the genus. This conservative assessment of the

500 taxon has allowed other specimens (e.g., Aetosauroides scagliai, Calyptosuchus wellesi) from

501 other areas (North and South America) to be easily assigned to the genus, mainly for the purpose

502 of building a global terrestrial vertebrate biostratigraphy for the Upper Triassic (e.g., Lucas \&

503 Heckert 1996; Heckert \& Lucas 1999, 2000, 2002; Lucas, Spielmann, \& Hunt 2007; Lucas

504 2017). However, detailed comparison demonstrates that these taxa all bear unique combinations

505 of characters that allow them to be differentiated (e.g., Desojo \& Ezcurra 2011; Parker 2018).

506 Assignment of specimens to genera can be subjective and based upon the taxonomic philosophy

507 of the researcher. I have argued elsewhere (e.g., Parker 2018) that utilizing monotypic genera in

508 aetosaurian work can aid in removing some of the ambiguity regarding use of these taxa in

509 broader scale studies where genera are often used as a proxy for species. Diagnoses should be

510 apomorphy-based, at the species level, or provide unique combinations of characters. Thus it is

511 important that holotype specimens be reexamined utilizing discrete apomorphies in a

512 phylogenetic context (Nesbitt, Irmis \& Parker 2007; Irmis et al. 2007; Nesbitt \& Stocker 2008;

513 Parker 2013). 
This is especially true when taxa are being utilized for intercontinental biostratigraphic

515

516

517

518

519

520

521

522

523

524

525

526

527

528

529

530

531

532

533

534 correlations (Irmis et al. 2010). For another example of how taxa may be lumped based on

plesiomorphies for biostratigraphic convenience, a recent discussion on global biostratigraphy

for the Late Triassic proposes a new hypothesis that Neoaetosauroides engaeus is a junior

subjective synonym of Aetosaurus ferratus (Lucas 2017). Support is given based on the

width/length ratios and ornamentation patterns of the paramedian osteoderms (both

symplesiomorphies for Aetosauria based on their presence in the non-stagonolepidid

Aetosauroides scagliai) as well as an interpretation of similar sutural patterns of the skull based

on published figures (Lucas 2017:369). However, this interpretation ignores several key

characters such as the presence of a laterally expanded premaxillary tip in Neoaetosauroides

engaeus (Desojo \& Báez 2007), which is apomorphic for many aetosaurians (Parker 2016a;

Hoffman, Heckert \& Zanno 2018) although absent in Aetosaurus ferratus (Schoch 2007) as well

as Aetosauroides scagliai, which polarizes the character distribution. Among other character

differences with $A$. ferratus, $N$. engaeus also lacks a well-developed antorbital fossa. Thus,

synonomy between the two taxa is based on overall general similarity and symplesiomorphy

rather than discrete synapomorphies, and currently unsupported. The practice of using

plesiomorphic characters to assign specimens and to synonymize taxa has long been out of favor

in vertebrate paleontology and should no longer be acceptable (e.g., Sereno 1990; Padian,

Lindberg \& Polly 1994; see further discussion in Nesbitt \& Stocker 2008). Data that utilize this

approach should be strongly suspect and not used for broader scale studies until the

synapomorphy distributions among included taxa are fully evaluated and supported. 
535 Status of the holotype of Stagonolepis robertsoni Agassiz, 1844

536 The holotype of Stagonolepis robertsoni is the impression of a fragment of the ventral

537 carapace of a single specimen (ELGNM 27R) that shows several partial rows and columns of

538 imbricated predominantly rectangular osteoderms (Figure 11; Huxley 1877:pl.1, fig. 1). These

539 osteoderms have an anterior bar and a surface pattern of numerous drop-shaped pits radiating

540 from the osteoderm center; hence the name Stagonolepis, which means "drop scale". Since the

541 initial descriptions by Huxley (1877) and Walker (1961) subsequent authors have assigned other

542 species to Stagonolepis robertsoni based on similarities of the dorsal paramedian osteoderms

543 (e.g., Murry \& Long 1989; Long \& Murry 1995; Lucas \& Heckert 2001; Heckert \& Lucas 2002;

544 Lucas et al. 2007b). However, none of these authors have addressed the diagnostic status of the

545 type specimen.

$546 \quad$ Ventral osteoderms are known from several other aetosaurian taxa including

547 Coahomasuchus kahleorum, Calyptosuchus wellesi, Scutarx deltatylus, Neoaetosauroides

548 engaeus, Aetosaurus ferratus, and even the non-aetosaurian Revueltosaurus callenderi.

549 However, as described above presently the ornamentation in the ventral osteoderms of the

550 holotype specimen (ELGNM 27R) of S. robertsoni differs from that of other aetosaurians in that

551 it consists of randomly arranged oblong pits separated by a latticework of thin ridges. These pits

552 are tightly packed and cover the majority of the osteoderm surface. This differs from what is

553 seen in other aetosaurian taxa where the ornamentation consists of narrow grooves and oblong

554 pits radiating from a central point on the osteoderm, and presently Stagonolepis robertsoni is

555 currently valid based on this character as well as the unique combination of characters listed and

556 discussed above. A similar patterning is found in what is thought to be ventral osteoderms in the

557 purported aetosaurian Chilenosuchus forttae Casamiquela 1980 (Desojo 2003); however, the

558 aetosaurian affinities of this taxon are uncertain (Desojo et al. 2013). Regardless even if $C$. 
559 forttae is shown to unambiguously represent an aetosaur, it can still be distinguished from $S$.

560 robertsoni by the ornamentation of the dorsal osteoderms, which lack a radial pattern in $C$.

561 forttae (Desojo, 2003). However, this might necessitate the designation of a neotype specimen to

562 conserve the name Stagonolepis robertsoni as the holotype specimen will no longer be

563 diagnostic and the taxon valid only based on a unique combination of characters (Parker 2008b,

564 2014).

565

566 CONCLUSIONS

567 Stagonolepis robertsoni is the oldest named aetosaurian and as such has long served as

568 the standard for aetosaurian osteology. Despite this status, the material is difficult to work with

569 because of its preservation and because the only sites where $S$. robertsoni fossils have been

570 recovered are no longer active. However, the holotype specimen, although fragmentary, is

571 presently diagnostic and Walker's (1961) description is extremely faithful to the existing

572 material and still serves as the basis for our understanding of this taxon.

573 In this contribution I redescribe and note several features that have recently become

574 important characters for the purpose of comparing aetosaurians taxonomically and

575 phylogenetically. S. robertsoni has a paramedian osteoderm morphology that bears a unique

576 combination of characters including a raised anterior bar with anteromedial, anterior, and

577 anterolateral processes (projections), a 'scalloped' anterior edge of the anterior bar medial to the

578 anterior process, a short anterolateral process, a posteriorly placed, pyramidal dorsal eminence,

579 and an anastomosing pattern of pits and grooves radiating from the eminence that lacks elongate

580 nearly parallel grooves. Furthermore, the posterior portion of the paramedian osteoderms are

581 devoid of ornament. S. robertsoni is also the only aetosaurian to preserve an extremely elongate

582 first cervical rib, which possibly is an autapomorphy of the taxon. Posterior cervical vertebrae 
583 are keeled ventrally and bear diapophyseal and zygapophyseal laminae. The parabasisphenoid is

584 anteroposteriorly elongate with significant separation between the basitubera and the

585 basipterygoid processes. The ventral osteoderms have an autapomorphic ornamentation.

586 These characters serve to differentiate $S$. robertsoni from all other aetosaurs including

587 those who are or have been historically assigned to the same genus including Stagonolepis

588 olenkae, Calyptosuchus wellesi, and Aetosauroides scagliai. These assignments were made

589 based on general similarity and symplesiomorphies rather than synapomorphies, a practice that is

590 widely discouraged in vertebrate paleontology.

591

592 INSTITUTIONAL ABBREVIATIONS

593 ELGNM Elgin Museum, Elgin, Scotland

594 MCP Museo de Ciencias e Tecnología, Porto Alegre, Brazil

595 MACN Museo Museo Argentino de Ciencias Naturales 'Bernardino Rivadavia', Buenos

$596 \quad$ Aires, Argentina

597 MCZD University of Aberdeen Zoology Department, Aberdeen, Scotland

598 MNA Museum of Northern Arizona, Flagstaff, Arizona, USA

599 NHMUK Natural History Museum, United Kingdom

600 PEFO Petrified Forest National Park, Petrified Forest, Arizona, USA

601 PVL Paleontología de Vertebrados, Instituto "Miguel Lillo," San Miguel de Tucumán,

$602 \quad$ Argentina

603 PVSJ División de Paleontologia de Vertebrados del Museo de Ciencias Naturales y

$604 \quad$ Universidad Nacional de San Juan, San Juan, Argentina 
605 TMM Texas Vertebrate Paleontology Collections, University of Texas, Austin, Texas, $606 \quad$ USA

607 UCMP University of California Museum of Paleontology, Berkeley, CA, USA

608 UMMP University of Michigan Museum of Paleontology, Ann Arbor, Michigan, USA

609 USFM Universidade Federal de Santa Maria, Santa Maria, Brazil

610 YPM Yale Peabody Museum of Natural History, New Haven, Connecticut, USA

611 ZPAL Institute of Paleobiology, Polish Academy of Sciences, Warsaw, Poland

612

613 ACKNOWLEDGEMENTS

614 Thank you to Sandra Chapman (NHMUK), Lorna Steele (NHMUK), David Gower 615 (NHMUK), Julia Desojo (MACN), Mark Goodwin (UCMP), Kevin Padian (UCMP), the late 616 Jaime Powell (PVL); Ricardo Martinez (PVSJ), David \& Janet Gillette (MNA), and Matthew

617 Smith (PEFO) for access to specimens and data under their control as well as discussions. Thank 618 you to Jeffrey Martz for discussions. An earlier version of the manuscript was completed under 619 the partial requirements of a dissertation at the University of Texas by the senior author. Careful 620 reviews by Richard Butler, Michael Benton, Julia Desojo, Jeffrey Martz, and academic editor 621 Mark Young improved the manuscript. This is Petrified Forest National Park Paleontological 622 Contribution \#56. The work presented here is that of the author and does not represent the views 623 or opinions of the United States Government.

\section{4}

625

REFERENCES

626 Agassiz L. 1844. Monographie des poissons fossiles du vieux grès rouge ou Système Dévonien (Old Red Sandstone) des Isles Britanniques et de Russie. Jent et Gassman, Neuchâtel, 171 pp. 
629 Antczak M. 2016. Late Triassic aetosaur (Archosauria) from Krasiejów (SW Poland): new 630 species or an example of individual variation? Geological Journal 51:779-788.

631 Benton MJ, Walker AD. 2011. Saltopus, a dinosauriform from the Upper Triassic of Scotland. 632 Earth and Environmental Transactions of the Royal Society of Edinburgh 101:285-299.

633

634

635

636

637

638

639

640

641

642

643

644

645

646

647

648

649

650

651

Bonaparte JF. 1978. El Mesozoico de America del Sur y sus tetrapodos. Opera Lilloana 26:1596.

Carroll RL. 1988. Vertebrate Paleontology and Evolution. W.H. Freeman and Company, New York, 698 pp.

Casamiquela RM. 1960. Notica preliminar sobre dos nuevos estagonolepoideos Argentinos. Ameghiniana 2:3-9.

Casamiquela RM. 1980. Nota sobre restos de un reptile aetosauroideo (Thecodontia, Aetosauria) de Quimal, Cordillera de Domeyko, Antofagasta. Prueba de la existencia del Neotriásico continental en los Andes del Norte de Chile. In: Congreso Argentino de Paleontología y Bioestratigrafía, No. 2 y Congreso Latinoamericano de Paleontología, Volume 1. Asociación Paleontológica Argentina, Buenos Aires, 135-142.

Case EC. 1920. Preliminary description of a new suborder of phytosaurian reptiles with a description of a new species of Phytosaurus. Journal of Geology 28:524-535.

Case EC. 1922. New reptiles and stegocephalians from the Upper Triassic of western Texas. Carnegie Institution of Washington Publication 321:1-84.

Cope ED. 1869. Synopsis of the extinct Batrachia, Reptilia, and Aves of North America. Transactions of the American Philosophical Society 14:1-252.

Cope ED. 1875. Report on the geology of that part of northwestern New Mexico examined during the fieldseason of 1874. In: Wheeler, G. M. (ed.) Annual Report upon the 
652

653

654

655

656

657

658

659

660

661

662

663

664

665

666

667

668

669

670

671

672

673

674

Geographical Explorations West of the Hundredth Meridian in California, Nevada, Nebraska, Utah, Arizona, Colorado, New Mexico, Wyoming and Montana [Wheeler Survey]. US GPO, Washington, DC, Appendix LL, Annual Report Chief of Engineers for $1875,61-97$ of separate issue, $981-1017$ of full report.

Desojo JB. 2003. Redescripción del aetosaurio Chilenosuchus forttae Casamiquela (Diapsida: Arcosauria): presencia de Triásico continental en el norte de Chile. Revista Gelógica de Chile 30:53-63.

Desojo JB, Báez AM. 2007. Cranial morphology of the Late Triassic South American archosaur Neoaetosauroides engaeus: evidence for aetosaurian diversity. Palaeontology 50:267276.

Desojo JB, Ezcurra MD. 2011. A reappraisal of the taxonomic status of Aetosauroides (Archosauria, Aetosauria) specimens from the Late Triassic of South America and their proposed synonymy with Stagonolepis. Journal of Vertebrate Paleontology 31:596-609.

Desojo JB, Vizcaíno SF. 2009. Jaw biomechanics in the South American aetosaur Neoaetosauroides engaeus. Paläontologische Zeitschrift 83:499-510.

Desojo JB, Ezcurra MD, Kischlat EE. 2012. A new aetosaur genus (Archosauria: Pseudosuchia) from the early Late Triassic of southern Brazil. Zootaxa 3166:1-33.

\section{Desojo JB, Heckert AB, Martz JW, Parker WG, Schoch RR, Small BJ, Sulej T. 2013.} Aetosauria: a clade of armored pseudosuchians from the Upper Triassic continental beds. In: Nesbitt SJ, Desojo J B, Irmis RB, eds. Anatomy, Phylogeny, and Palaeobiology of Early Archosaurs and their Kin. Geological Society, London, Special Publications 379. The Geological Society Publishing House, Bath, 203-239.Fraser NC. 1988. Latest Triassic vertebrates and their biostratigraphy. Modern Geology 13:125-140. 
675 Fraas O. 1877. Aetosaurus ferratus Fr. Die gepanzerte Vogel-Echse aus dem Stubensandstein

676

677

678

679

680

681

682

683

684

685

686

687

688

689

690

691

692

693

694

695 bei Stuttgart. Festschrift zur Feier des vierhundertjährigen Jubilaüms der Eberhard-KarlsUniversität zu Tübingen. Wurttembergische Naturwissenschaftliche Jahreshefte 33:1-22.

Gauthier JA, Padian K. 1985. Phylogenetic, functional, and aerodynamic analyses of the origin of birds and their flight. In: Hecht MK, Ostrom JH, ViohlG, Wellnhofer P. eds. The Beginning of Birds: Proceedings of the International Archaeopteryx Conference, Eichstätt, 1984. Freunde des Jura-Museums Eichstätt, Eichstätt, 185-197.

Gower DJ, Walker AD. 2002. New data on the braincase of the aetosaurian archosaur (Reptilia: Diapsida) Stagonolepis robertsoni Agassiz; pp. 7-23 in Norman D. B. and D. J. Gower (eds.), Archosaurian Anatomy and Paleontology. Essays in Memory of Alick D. Walker. Zoological Journal of the Linnaean Society 136. The Linnaean Society of London, London.

Heckert AB, Lucas SG. 1999. A new aetosaur (Reptilia: Archosauria) from the Upper Triassic of Texas and the phylogeny of aetosaurs. Journal of Vertebrate Paleontology 19:50-68.

Heckert AB, Lucas SG. 2000. Taxonomy, phylogeny, biostratigraphy, biochronology, paleobiogeography, and evolution of the Late Triassic Aetosauria (Archosauria: Crurotarsi). Zentralblatt für Geologie und Paläontologie Teil I 1998 Heft 11-12:15391587.

Heckert AB, Lucas SG. 2002. South American occurrences of the Adamanian (Late Triassic: latest Carnian) index taxon Stagonolepis (Archosauria: Aetosauria) and their biochronological significance. Journal of Paleontology 76:852-863. 
696 Heckert AB, Hunt AP, Lucas SG. 1996. Redescription of Redondasuchus reseri, a Late

697

698

699

700

701

702

703

704

705

706

707

708

709

710

711

712

713

714

715

716

717

718

Triassic aetosaur (Reptilia: Archosauria) from New Mexico (U.S.A.), and the biochronology and phylogeny of aetosaurs. Geobios 29:619-632.

Heckert AB, Lucas SG, Rinehart LF, Celeskey MD, Spielmann JA, Hunt AP. 2010. Articulated skeletons of the aetosaur Typothorax coccinarum Cope (Archosauria: Stagonolepididae) from the Upper Triassic Bull Canyon Formation (Revueltian: earlymid Norian), eastern New Mexico, USA. Journal of Vertebrate Paleontology 30:619642.

Heckert AB, Schneider VP, Fraser NC, Webb RA. 2015. A new aetosaur (Archosauria: Suchia) from the Upper Triassic Pekin Formation, Deep River Basin, North Carolina, U. S. A., and its implications for early aetosaur evolution. Journal of Vertebrate Paleontology 35:e881831.

Heckert AB, Fraser NC, Schneider VP. 2017. A new species of Coahomasuchus (Archosauria, Aetosauria) from the Upper Triassic Pekin Formation, Deep River Basin, North Carolina. Journal of Paleontology 91:162-178.

Hoffman DK, Heckert AB, Zanno LE. 2018. Under the armor: X-ray computed tomographic reconstruction of the internal skeleton of Coahomasuchus chathamensis (Archosauria: Aetosauria) from the Upper Triassic of North Carolina, USA, and a phylogenetic analysis of Aetosauria. PeerJ 6:e4368.Huene F. 1902. Übersicht über die reptilien der Trias. Geologische und Palaeontologische Abhandlungen n. F. 6:1-84.

Huene F.1908. Die dinosaurier der europäischen Triasformation mit Berücksichtigung der aussereuropäischen Vorkommnisse. Geologische und Palaeontologische Abhandlungen Suppl-Bd. 1:322-351. 
719 Huene F. 1936. The constitution of the Thecodontia. American Journal of Science 32:207-217.

720 Huene F.1942. Die fossilen Reptilien des südamerikanischen Gonwanalandes. Ergebnisse dur

721

722

723

724

725

726

727

728

729

730

731

732

733

734

735

736

737

738

739

740 Sauriergrabung in Südbrasilien 1928/1929. C.H. Beck, München.

Hillis DM, Bull JJ. 1993. An empirical test of bootstrapping as a method for accessing confidence in phylogenetic analysis. Systematic Biology 42:182-192.

Huxley TH. 1859. On the Stagonolepis robertsoni (Agassiz) of the Elgin Sandstone; and on the recently discovered footmarks in the Sandstones of Cummingstone. Proceedings of the Geological Society 15:440-460.

Huxley TH. 1869. On Hyperodapedon. Quarterly Journal of the Geological Society, London 25:138-152.

Huxley TH. 1875. On Stagonolepis robertsoni, and on the evolution of the crocodylia. Quarterly Journal of the Geological Society, London 31:423-438.

Huxley TH. 1877. The crocodilian remains found in the Elgin sandstones, with remarks on the ichnites of Cummingstone. Memoirs of the Geological Survey of the United Kingdom 3:1-58.

Irmis RB, Parker WG, Nesbitt SJ, Liu J. 2007. Early ornithischian dinosaurs: the Triassic record. Historical Biology 19:3-22.

Irmis RB, Martz JW, Parker WG, Nesbitt SJ. 2010. Re-evaluating the correlation between Late Triassic terrestrial vertebrate biostratigraphy and the GSSP-defined marine stages. Albertiana 38:40-52.

Krebs B. 1976. Pseudosuchia. In: Kuhn O, ed. Handbuch der Paläoherpetologie, Volume13. Gustav Fischer Verlag, Stuttgart, 40-98. 
741 Kuhn O. 1936. Weitere Parasuchier und Labyrinthodonten aus dem Blasensandstein des

742

743

744

745

746

747

748

749

750

751

752

753

754

755

756

757

758

759

760

761

762

763 mittleren Keuper von Ebrach. Palaontographica (A) 83:61-98.

Long RA, Ballew KL. 1985. Aetosaur dermal armor from the Late Triassic of southwestern North America, with special reference to material from the Chinle Formation of Petrified Forest National Park. In: Colbert EH, Johnson RR, eds. The Petrified Forest Through the Ages, $75^{\text {th }}$ Anniversary Symposium November 7, 1981. Museum of Northern Arizona Bulletin 54. Museum of Northern Arizona Press, Flagstaff, 45-68.

Long RA, Murry PA. 1995. Late Triassic (Carnian and Norian) tetrapods from the southwestern United States. New Mexico Museum of Natural History and Science Bulletin 4:1-254.

Lucas SG. 2017. Late Triassic terrestrial tetrapods: biostratigraphy, biochronology, and biotic events. In: Tanner LH, ed., The Late Triassic World, Topics in Geobiology 46, Springer International Publishing AG, Cham, Switzerland, 351-405.

Lucas SG, Heckert AB. 1996. Late Triassic aetosaur biochronology. Albertiana 17:57-64.

Lucas SG, Heckert AB. 2001. The aetosaur Stagonolepis from the Upper Triassic of Brazil and its biochronological significance. Neues Jahrbuch für Geologie und Paläontologie, Monatshefte 2001:719-732.

Lucas SG, Hunt AP, Spielmann JA. 2007. A new aetosaur from the Upper Triassic (Adamanian: Carnian) of Arizona. New Mexico Museum of Natural History and Science Bulletin 40:241-247.

Lucas SG, Spielmann JA, Hunt AP. 2007. Biochronological significance of Late Triassic tetrapods from Krasiejów, Poland. In: Lucas SG, Spielmann JA, eds., The Global Triassic. New Mexico Museum of Natural History and Science Bulletin 41. New Mexico Museum of Natural History and Science, Albuquerque, 248-258. 
764 Lucas SG, Hunt AP, Heckert AB, Spielmann, JA. 2007b. Global Triassic tetrapod

765 biostratigraphy and biochronology: 2007 status. In: Lucas SG, Spielmann JA, eds. The

766 Global Triassic. New Mexico Museum of Natural History and Science Bulletin 41. New

767 Mexico Museum of Natural History and Science, Albuquerque, 229-240.

768

Marsh OC. 1884. The classification and affinities of dinosaurian reptiles. Nature 31:68-69.

Martz JW. 2002. The morphology and ontogeny of Typothorax coccinarum (Archosauria, Stagonolepididae) from the Upper Triassic of the American Southwest. Unpublished MS thesis, Texas Tech University, Lubbock, TX.

Martz JW, Small BJ. 2006. Tecovasuchus chatterjeei, a new aetosaur (Archosauria: Aetosauria) from the Tecovas Formation (Upper Triassic, Carnian) of Texas. Journal of Vertebrate Paleontology 26:308-320.

\section{Martz JW, Mueller B, Nesbitt SJ, Stocker MR, Parker WG, Atanassov M, Fraser N,} Weinbaum J, Lehane JR. 2012. A taxonomic and biostratigraphic re-evaluation of the Post Quarry vertebrate assemblage from the Cooper Canyon Formation (Dockum Group, Upper Triassic) of southern Garza County, western Texas. Earth and Environmental Science Transactions of the Royal Society of Edinburgh 103:339-364.

Murry PA, Long RA. 1989. Geology and paleontology of the Chinle Formation, Petrified Forest National Park and vicinity, Arizona and a discussion of vertebrate fossils of the southwestern Upper Triassic. In: Lucas SG and Hunt AP, eds. Dawn of the Age of Dinosaurs in the American Southwest. New Mexico Museum of Natural History, Albuquerque, 29-64. 
785 Nesbitt SJ, Stocker MR. 2008. The vertebrate assemblage of the Late Triassic Canjilon Quarry

786

787

788

789

790

791

792

793

794

795

796

797

798

799

800

801

802

803

804

805

(northern New Mexico, U.S.A.), and the importance of apomorphy-based assemblage comparisons. Journal of Vertebrate Paleontology 28:1063-72.

Nesbitt SJ, Irmis RB, Parker WG. 2007. A critical re-evaluation of the Late Triassic dinosaur taxa of North America. Journal of Systematic Palaeontology 5:209-243.

Padian K, Lindberg DR, Polly PD. 1994. Cladistics and the fossil record: the uses of history. Annual Review of Earth and Planetary Science, 22, 63-91.

Parker WG. 2005. A new species of the Late Triassic aetosaur Desmatosuchus (Archosauria: Pseudosuchia). Compte Rendus Paleovol 4:327-340.

Parker WG. 2007. Reassessment of the aetosaur "Desmatosuchus" chamaensis with a reanalysis of the phylogeny of the Aetosauria (Archosauria: Pseudosuchia). Journal of Systematic Palaeontology 5:1-28.

Parker WG. 2008a. Description of new material of the aetosaur Desmatosuchus spurensis (Archosauria: Suchia) from the Chinle Formation of Arizona and a revision of the genus Desmatosuchus. PaleoBios 28:1-40.

Parker WG. 2008b. How many valid aetosaur species are there? Reviewing the alpha-taxonomy of the Aetosauria (Archosauria: Pseudosuchia) and its implications for Late Triassic global biostratigraphy [Abstract]. Journal of Vertebrate Paleontology 28(supplement 3): $125 \mathrm{~A}$.

Parker WG. 2013. Redescription and taxonomic status of specimens of Episcoposaurus and Typothorax, the earliest known aetosaurs (Archosauria: Suchia) from the Upper Triassic 
of western North America, and the problem of "proxy" holotypes. Earth and Environmental Science Transactions of the Royal Society of Edinburgh 103:313-338.

808

809

810

811

812

813

814

815

Parker WG. 2014. Taxonomy and phylogeny of the Aetosauria (Archosauria: Pseudosuchia) including a new species from the Upper Triassic of Arizona. The University of Texas at Austin. Ph.D. dissertation, 437p.

Parker WG. 2016a. Revised phylogenetic analysis of the Aetosauria (Archosauria: Pseudosuchia); assessing the effects of incongruent morphological character sets. PeerJ 4:e1583; DOI 10.7717/peerj.1583.

Parker WG. 2016b. Osteology of the Late Triassic aetosaur Scutarx deltatylus (Archosauria: Pseudosuchia). PeerJ 4:e2411; DOI 10.7717/peerj.2411.

Parker WG. 2018. Redescription of Calyptosuchus (Stagonolepis) wellesi (Archosauria: Pseudosuchia: Aetosauria) from the Late Triassic of the southwestern United States with a discussion of genera in vertebrate paleontology. PeerJ 6:e4291; DOI 10.7717/ peerj.4291.

Parker WG, Martz JW. 2010. Using positional homology in aetosaur (Archosauria: Pseudosuchia) osteoderms to evaluate the taxonomic status of Lucasuchus hunti. Journal of Vertebrate Paleontology 30:1100-1108.

Parker WG, Stocker MR, Irmis RB. 2008. A new desmatosuchine aetosaur (Archosauria: Suchia) from the Upper Triassic Tecovas Formation (Dockum Group) of Texas. Journal of Vertebrate Paleontology 28:692-701.

Parrish JM. 1986. Locomotor adaptations in the hind limb and pelvis of the Thecodontia. Hunteria 1:3-35. 
828 Parrish JM. 1994. Cranial osteology of Longosuchus meadei and the phylogeny and distribution 829 of the Aetosauria. Journal of Vertebrate Paleontology 14:196-209.

830

831

832

833

834

835

836

837

838

839

840

841

842

843

844

845

846

847

848

849

850

Reese AM. 1915. The alligator and its allies. G.P. Putnam's Sons, New York, 358p.

Roberto-Da-Silva L, Desojo JB, Cabriera SF, Aires ASS, Müller ST, Pacheco CP, Dias-DaSilva S. 2014. A new aetosaur from the Upper Triassic of the Santa Maria Formation, southern Brazil. Zootaxa 3764(3):240-278.

Sawin HJ. 1947. The pseudosuchian reptile Typothorax meadei. Journal of Paleontology 21:201-238.

Schoch RR. 2007. Osteology of the small archosaur Aetosaurus from the Upper Triassic of Germany. Neues Jahrbuch für Geologie und Paläontologie, Abhandlungen 246:1-35.

Schoch RR, Desojo JB. 2016. Cranial anatomy of the aetosaur Paratypothorax andressorum Long \& Ballew, 1985, from the Upper Triassic of Germany and its bearing on aetosaur phylogeny. Neues Jahrbuch für Geologie und Paläontologie, Abhandlungen 279:73-95.

Sereno PC. 1990. Grades and clades in dinosaur systematics. In: Carpenter K, Currie PJ, eds., Dinosaur Systematics: approaches and perspectives. Cambridge University Press, Cambridge, United Kingdom, 9-20.

Sereno PC. 1991. Basal archosaurs: phylogenetic relationships and functional implications. Society of Vertebrate Paleontology Memoir 2:1-53.

Small BJ. 2002. Cranial anatomy of Desmatosuchus haplocerus (Reptilia: Archosauria: Stagonolepididae). Zoological Journal of the Linnean Society 136:97-111.

Small BJ, Martz JW. 2013. A new aetosaur from the Upper Triassic Chinle Formation of the Eagle Basin, Colorado, USA. In: Nesbitt SJ, Desojo JB, Irmis RB, eds., Anatomy, Phylogeny and Palaeobiology of Early Archosaurs and their Kin. Geological Society, 
851

852

853

854

855

856

857

858

859

860

861

862

863

864

865

866

867

868

869

870

871

872

873

874

London, Special Publications 379: The Geological Society Publishing House, Bath, 393412

Sulej T. 2010. The skull of an early Late Triassic aetosaur and the evolution of the stagonolepidid archosaurian reptiles. Zoological Journal of the Linnean Society 158:860881.

Walker AD. 1961. Triassic reptiles from the Elgin Area: Stagonolepis, Dasygnathus, and their allies. Philosophical Transactions of the Royal Society of London 244:103-204.

Wilson JA. 1999. Vertebral laminae in sauropods and other saurischian dinosaurs. Journal of Vertebrate Paleontology 19:639-653.

Zittel KAv. 1887-1890. Handbuch der Palaeontologie. 1. Abteilung: Paläozoologie, Band 3, Vertebrata (Pisces, Amphibia, Reptilia, Aves). Druck and Verlag von R. Oldenbourg, Münich and Leipzig, 900 pp.

\section{FIGURES}

Figure 1. Casts of bones of Stagonolepis robertsoni. A) NHMUK PV R 4787a, 1885 cast which represents much of the lower portion of a skull. B) NHMUK PV R 4787, PVC cast of the same specimen that shows more details of the braincase and dorsal portion of the skull. Scale bars equal $1 \mathrm{~cm}$. Abbreviations: an, angular; art, articular; bpt, basipterygoid process; bs, parabasisphenoid; bt, basal tuber; d, dentary; fr, frontals; l, left; mx, maxilla; mpr, area of the medial pharyngeal recess; pa, parietal; pmx, premaxilla; pra, prearticular; pro, prootic; pt, pterygoid; qu, quadrate; r, right; sa, surangular. Elements from the left side have a prefix of l.; elements of the right side have a prefix of $\mathbf{r}$. 
875 Figure 2. NHMUK PV R 4787, cast of a right maxilla of Stagonolepis robertsoni in lateral A) 876 and medial B) views. Scale bar equals $1 \mathrm{~cm}$. Abbreviations: a.,articulation with listed element;

877 alv, alveoli; aof, antorbital fenestra; ap.m, ascending process of the maxilla; ju, jugal; la, 878 lacrimal; ms, medial shelf; na, nasal; pac, pneumatic accessory cavity; pmx, premaxilla; tr, 879 transverseridge.

880

881 Figure 3. Cast of the anterior part of the right side of the skull of Stagonolepis robertsoni 882 (ELGNM 38R) in lateral view. Scale bar equals $1 \mathrm{~cm}$. Abbreviations: en, external naris; mx, 883 maxilla; na, nasal; nr, nasal ridge; pmr, premaxillary ridge; pmx, premaxilla.

884

885

Figure 4. NHMUK PV R 4784a, casts of articulated sections of the presacral vertebral column in 886 lateral view including the rear of the skull through the fourth cervical position (A), and the

887 888 889 890

891

892

893

894

895

896

seventh through the twelfth presacral vertebrae (B). Scale bars equal $1 \mathrm{~cm}$. Abbreviations: cvr, cervical rib; k, ventral keel; oc, occipital condyle of the basicranium; parp, parapophysis; pcdl, posterior centrodiapophyseal lamina.

Figure 5. Casts of osteoderms of Stagonolepis robertsoni. A, left anterior dorsal caudal paramedian (NHMUK PV R 4790a) in dorsal view; B, right dorsal trunk lateral (NHMUK PV R 4789a) in dorsolateral view. Scale bar equals $1 \mathrm{~cm}$. Abbreviations: a., articulation with listed element; ab, anterior bar; alp, anterolateral projection; amp, anteromedial projection; de, dorsal eminence; df, dorsal flange; lf, lateral flange; sc, scalloping of anterior bar margin. 
897 Figure 6. Ventral osteoderms of Stagonolepis robertsoni. A) close-up of NHMUK PV R 27404

898 (positive cast of EM 27R, the holotype specimen of Stagonolepis robertsoni Agassiz

899 1844) in ventrolateral view showing the detail of the overlapping osteoderms; B) NHMUK PV R

$9004787 \mathrm{a}$, referred ventral osteoderm in ventral view.

901

902 Figure 7. NHMUK PV R 4789. Cast of medial side of right ilium in medial view. Scale bar $=2$

903 cm. Abbreviations: arsr2, articulation for sacral rib 2; ip, ischiadic peduncle; ost, osteoderm;

904 poab, postacetabular blade; pp, pubic peduncle; prab, preacetabular blade.

905

906 Figure 8. Phylogenetic analysis of the Aetosauria. The reduced strict consensus cladogram from 907 Parker 2016a, with all named clades. Decay indices and bootstrap values are shown for all nodes, 908 with bootstrap values under 70\% (the confidence threshold of Hillis \& Bull, 1993) shown in red. 909

910 Figure 9. Dorsal anterior caudal paramedian osteoderms of Stagonolepis. A) NHMUK PV R 911 4787a, left paramedian of Stagonolepis robertsoni in dorsal view; B) PAN ZPAL AbIII 57011, 912 left paramedian of Stagonolepis olenkae in dorsal view. Scale bars $=1 \mathrm{~cm}$.

913

914 Figure 10. Alternate phylogenetic hypothesis of the Aetosauria of Hoffman, Heckert, and Zanno 915 (2018) with clade names and decay indices for each node.

916

917 Figure 11. Cast of ELGNM 27R, the holotype specimen of Stagonolepis robertsoni Agassiz 918 1844. A series of imbricated osteoderms from the ventral trunk region. 


\section{Figure 1}

Casts of bones of Stagonolepis robertsoni.

(A) NHMUK R4787a, 1885 cast which represents much of the lower portion of a skull. (B) NHMUK R4787, PVC cast of the same specimen that shows more details of the braincase and dorsal portion of the skull. Scale bars equal $1 \mathrm{~cm}$. Abbreviations: an, angular; art, articular; bpt, basipterygoid process; bs, parabasisphenoid; bt, basal tuber; d, dentary; fr, frontals; I, left; $\mathrm{mx}$, maxilla; $\mathbf{m p r}$, area of the medial pharyngeal recess; pa, parietal; pmx, premaxilla; pra, prearticular; pro, prootic; pt, pterygoid; qu, quadrate; r, right; sa, surangular. Elements from the left side have a prefix of I.; elements of the right side have a prefix of $\mathbf{r}$. 

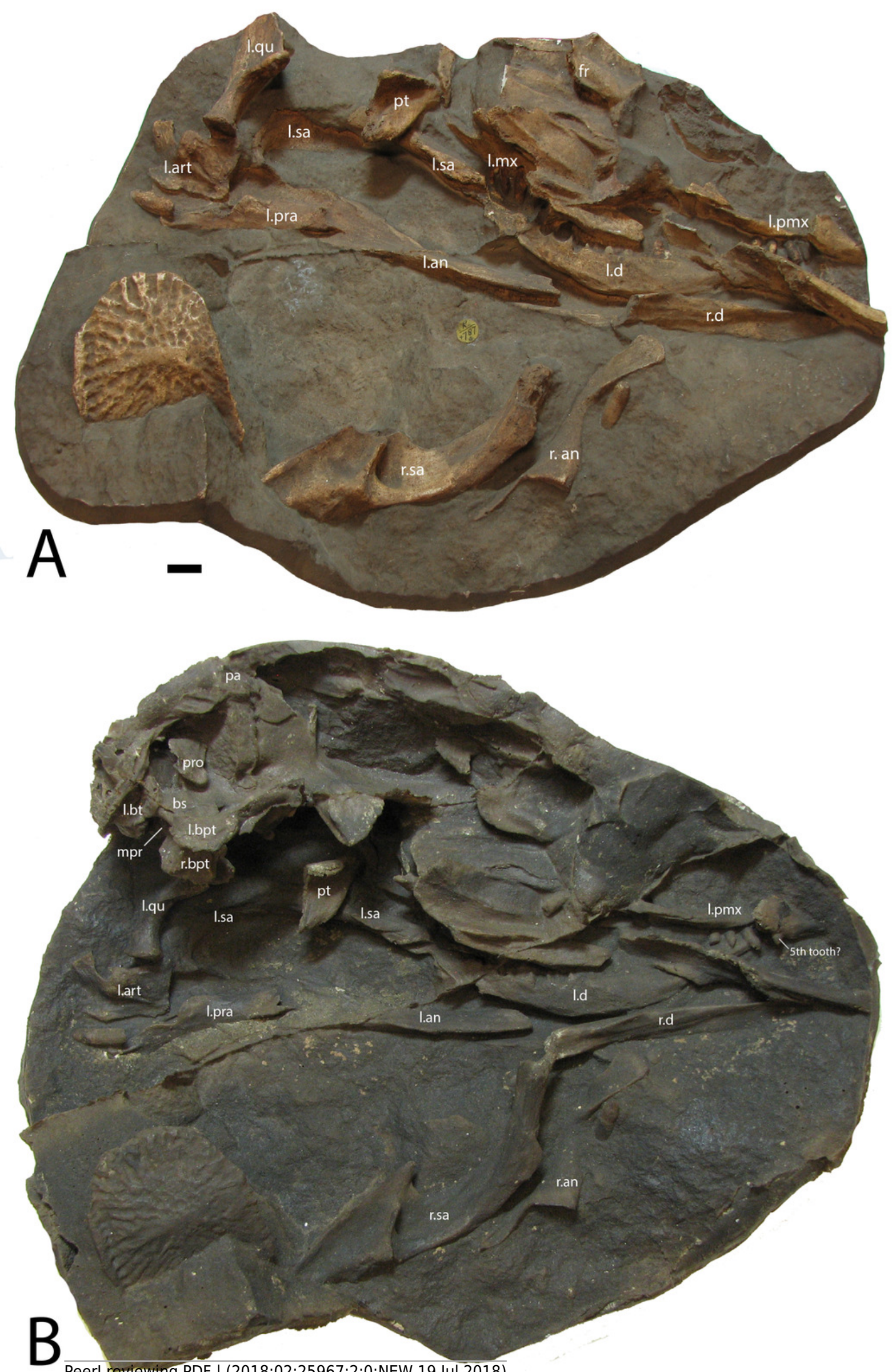

Peer) reviewing PDF | (2018:02:25967:2:0:NEW 19 Jul 2018) 


\section{Figure 2}

NHMUK R4787, cast of a right maxilla of Stagonolepis robertsoni

Lateral (A) and medial (B) views. Scale bar equals $1 \mathrm{~cm}$. Abbreviations: a.,articulation with listed element; alv, alveoli; aof, antorbital fenestra; ap.m, ascending process of the maxilla; ju, jugal; la, lacrimal; ms, medial shelf; na, nasal; pac, pneumatic accessory cavity; pmx, premaxilla; tr, transverse ridge. 


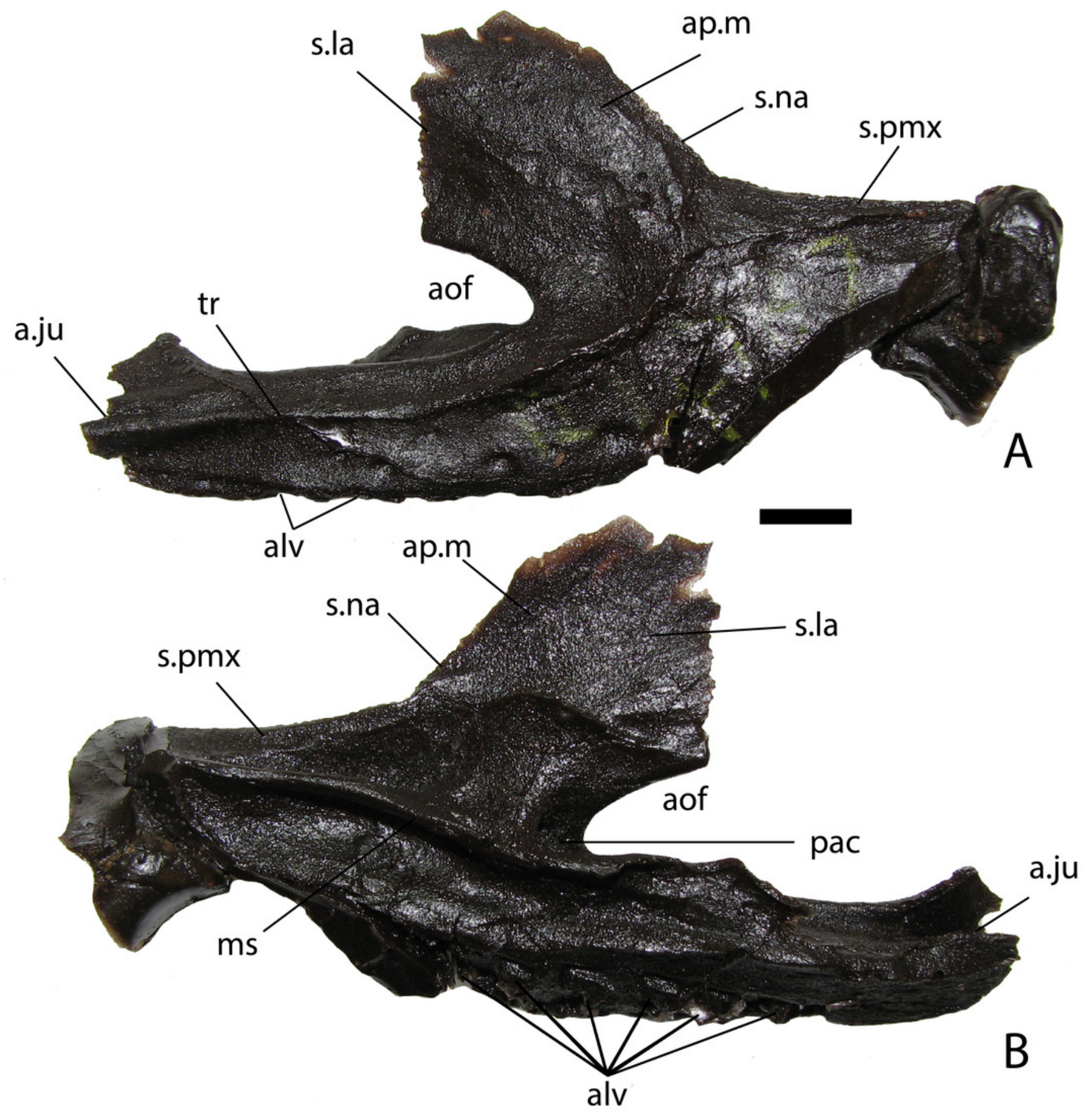




\section{Figure 3}

Skull of Stagonolepis robertsoni.

Cast of the anterior part of the right side of the skull of Stagonolepis robertsoni in lateral view. Scale bar equals $1 \mathrm{~cm}$. Abbreviations: en, external naris; $\mathbf{m x}$, maxilla; na, nasal; $\mathbf{n r}$, nasal ridge; pmr, premaxillary ridge; pmx, premaxilla.

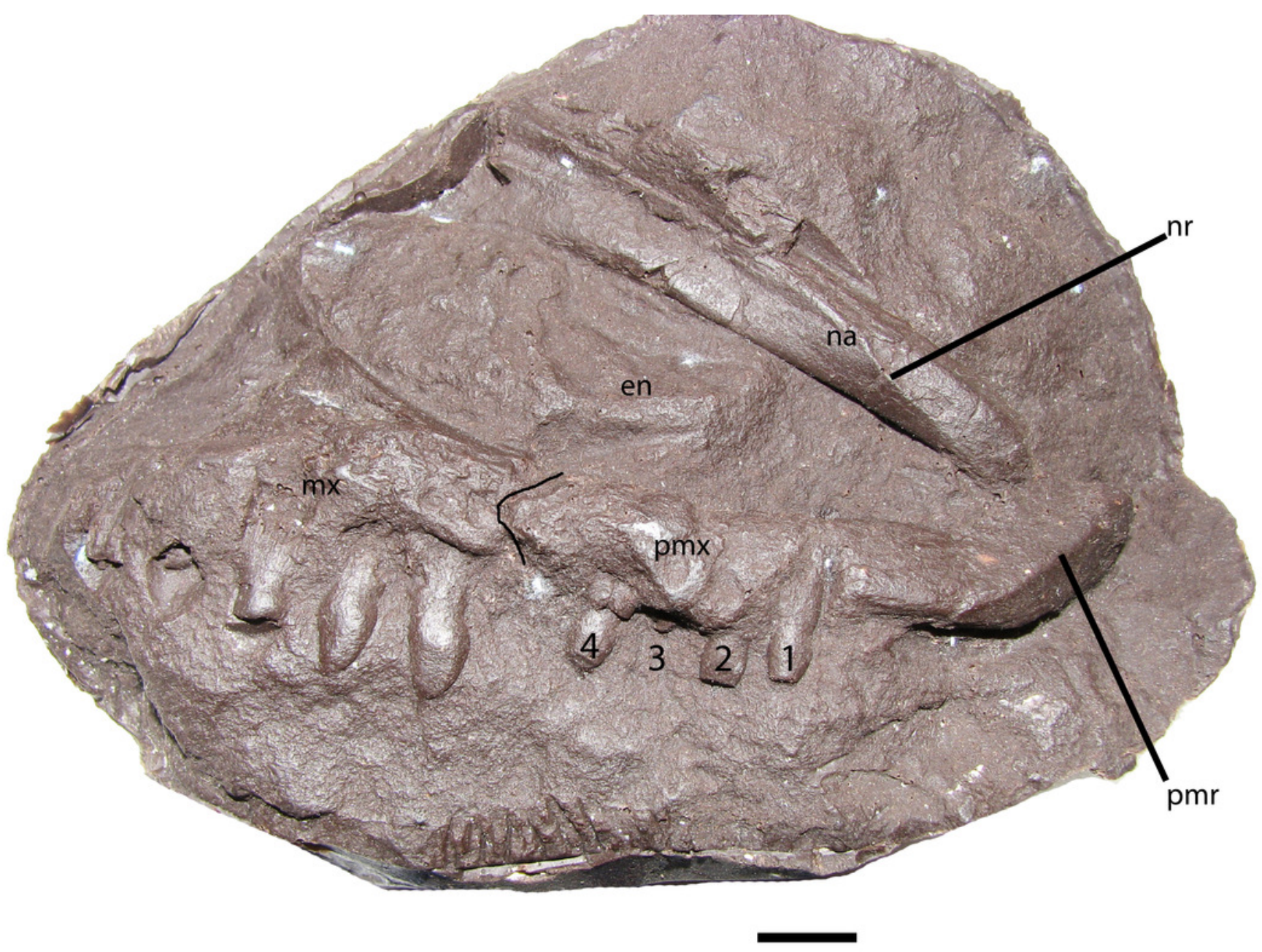




\section{Figure 4}

Presacral vertebrae of Stagonolepis robertsoni.

NHMUK 4784a, casts of articulated sections of the presacral vertebral column in lateral view including the rear of the skull through the fourth cervical position (A), and the seventh through the twelfth presacral vertebrae (B). Scale bars equal $1 \mathrm{~cm}$. Abbreviations: cvr, cervical rib; k, ventral keel; oc, occipital condyle of the basicranium; parp, parapophysis; pcdl, posterior centrodiapophyseal lamina. 

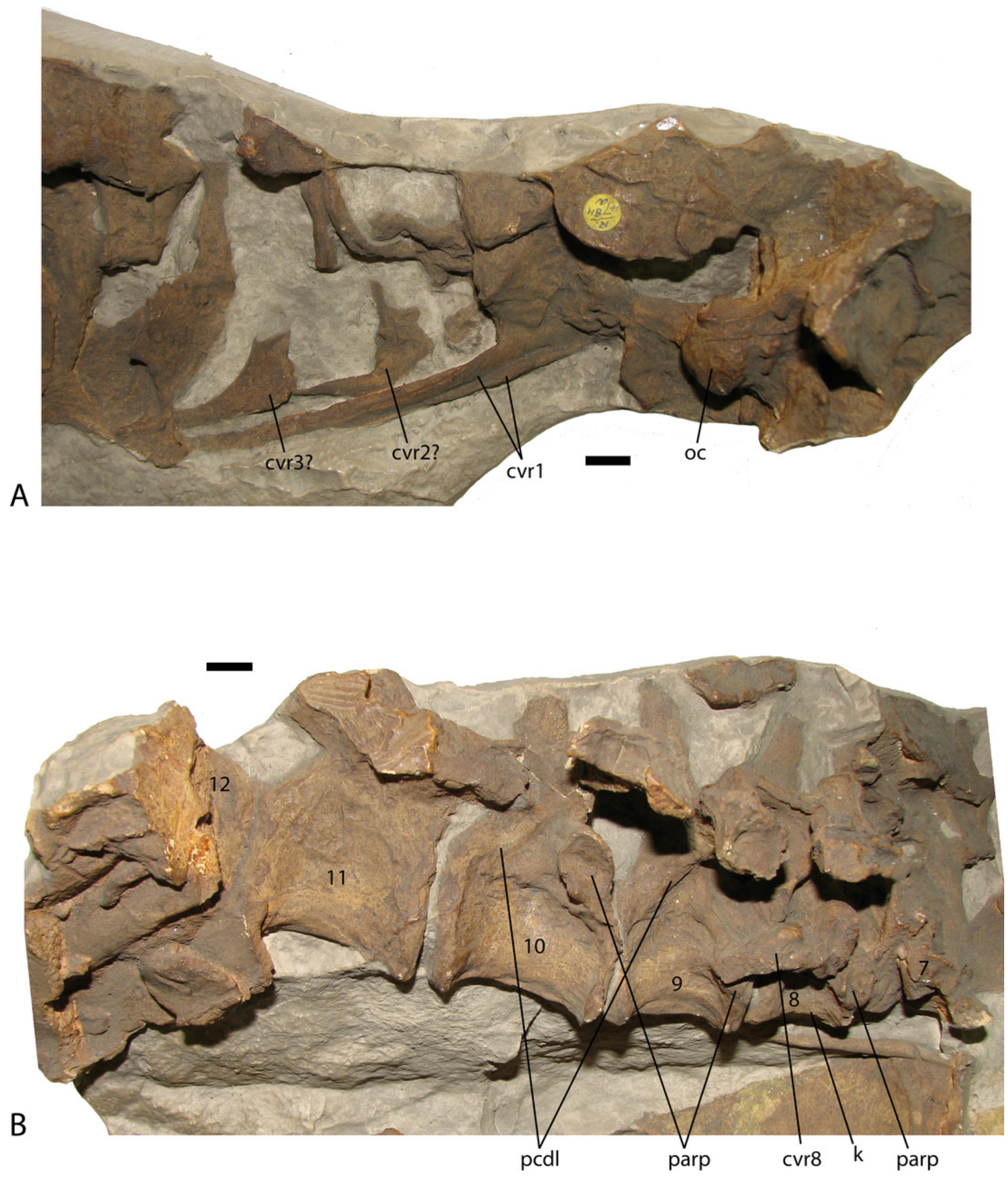


\section{Figure 5}

Casts of osteoderms of Stagonolepis robertsoni.

(A) left dorsal trunk paramedian (NHMUK R4790a) in dorsal view; (B) right dorsal trunk lateral (NHMUK R4789a) in dorsolateral view. Scale bar equals $1 \mathrm{~cm}$. Abbreviations: a., articulation with listed element; $\mathbf{a b}$, anterior bar; alp, anterolateral projection; amp, anteromedial projection; de, dorsal eminence; df, dorsal flange; If, lateral flange; sc, scalloping of anterior bar margin. 

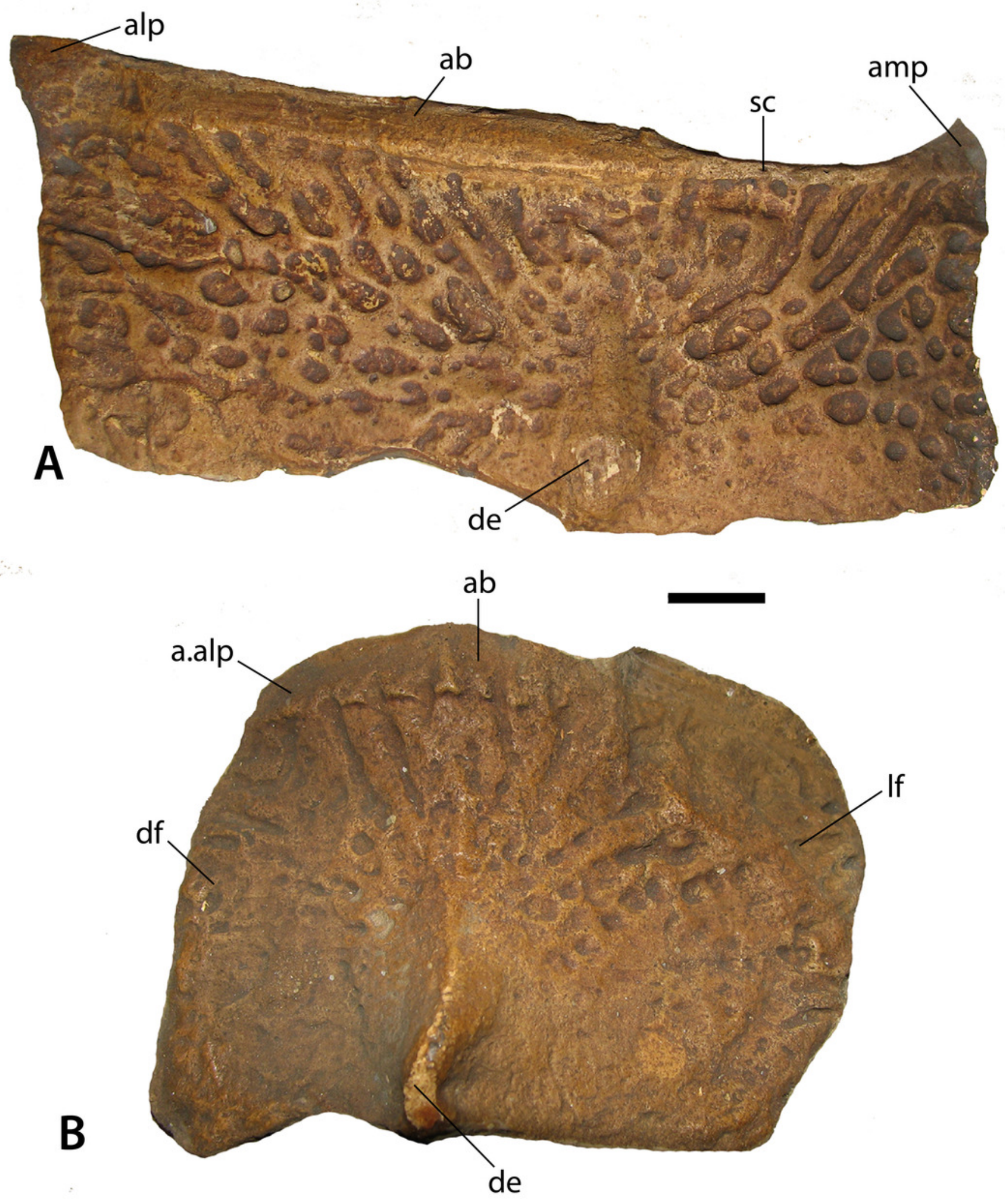


\section{Figure 6}

Ventral osteoderms of Stagonolepis robertsoni.

(A) close-up of NHMUK R27404 (positive cast of EM 27R, the holotype specimen of

Stagonolepis robertsoni Agassiz 1844) in ventrolateral view showing the detail of the overlapping osteoderms; (B) NHMUK R4787a, referred ventral osteoderm in ventral view.

Scale bar $=1 \mathrm{~cm}$.

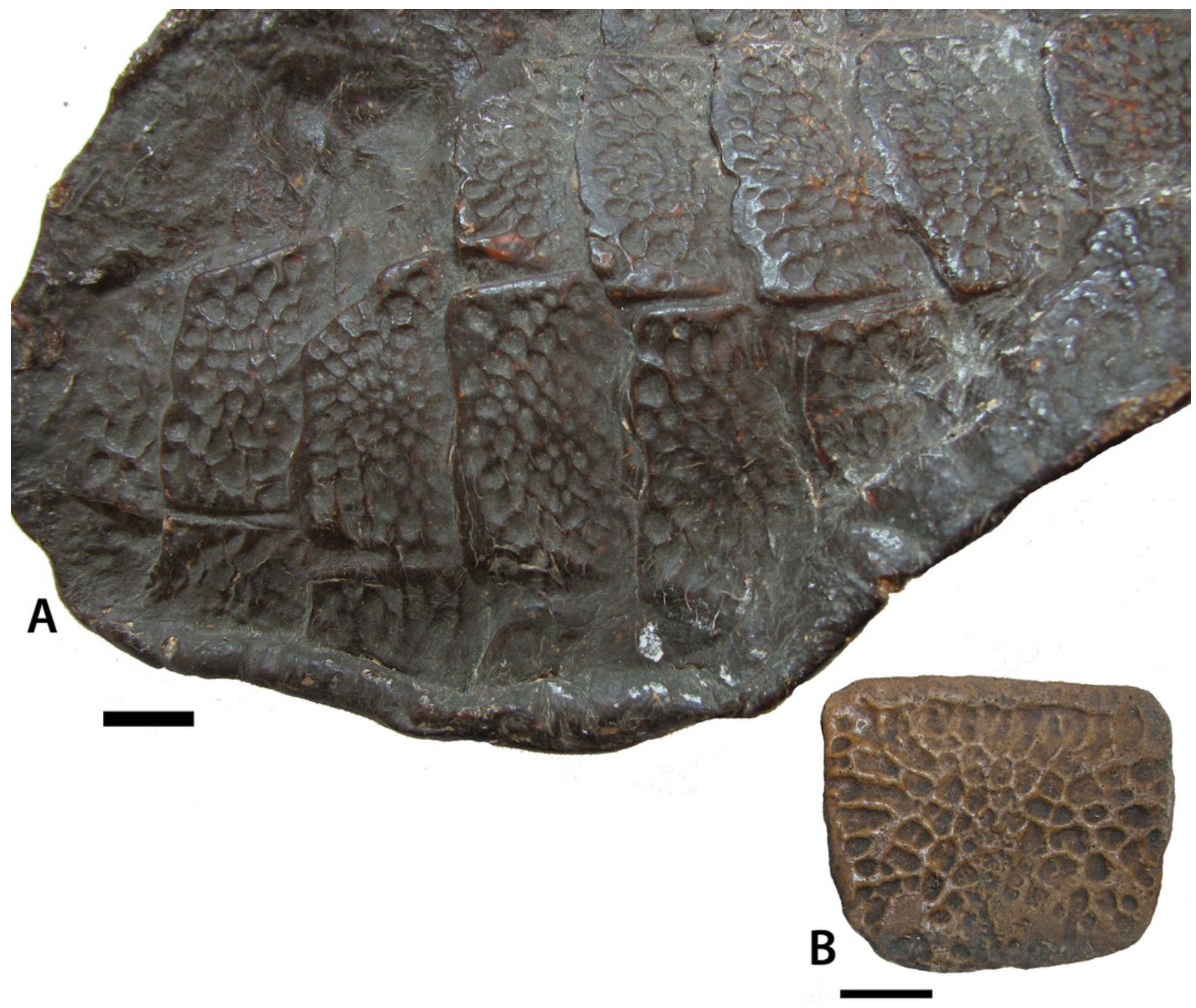




\section{Figure 7}

Ilium of Stagonolepis robertsoni

NHMUK R4789. Cast of medial side of right ilium in medial view. Scale bar $=2 \mathrm{~cm}$.

Abbreviations: arsr2, articulation for sacral rib 2; ip, ischiadic peduncle; ost, osteoderm; poab, postacetabular blade; pp, pubic peduncle; prab, preacetabular blade.

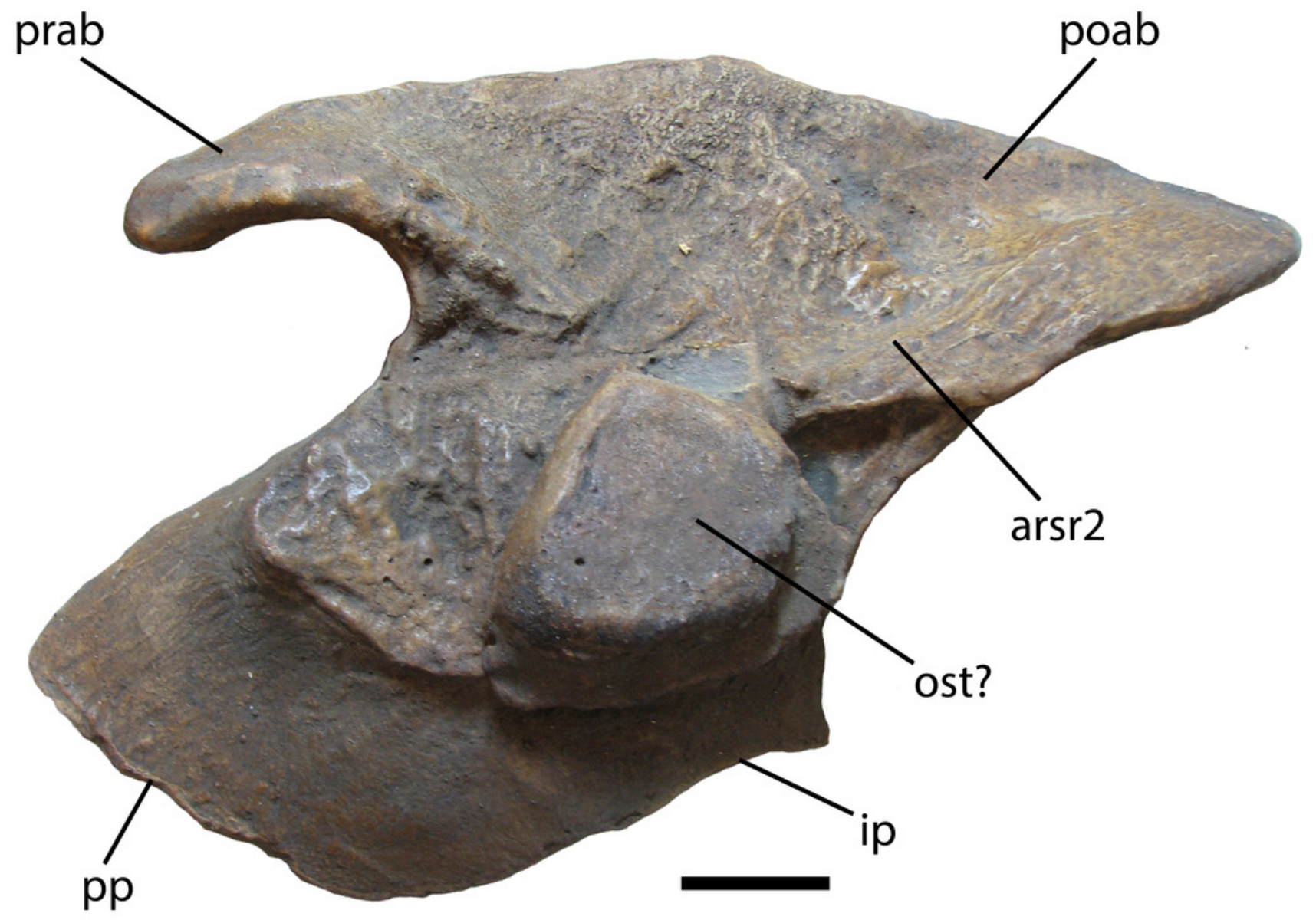




\section{Figure 8}

Phylogenetic Analysis of the Aetosauria.

The reduced strict consensus tree from Parker (2016a), with all named clades. Decay indices and bootstrap values are shown for all nodes, with bootstrap values under $70 \%$ (the confidence threshold of Hillis \& Bull, 1993) shown in red.

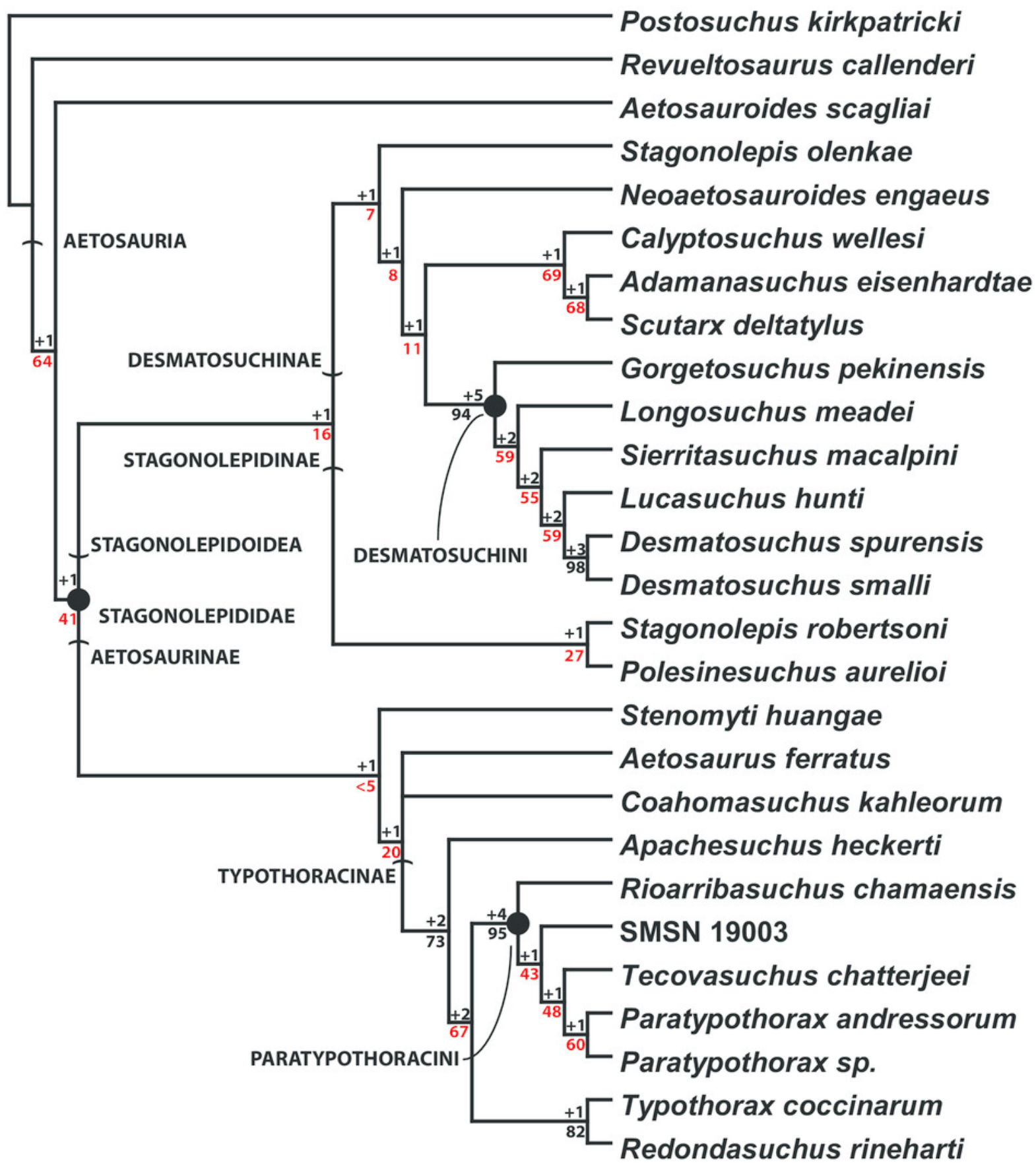




\section{Figure 9}

Dorsal trunk paramedian osteoderms of Stagonolepis.

(A) NHMUK R4787a, left dorsal trunk paramedian in dorsal view; (B) PAN ZPAL AbIII 57011, left dorsal trunk paramedian in dorsal view. Scale bars $=1 \mathrm{~cm}$. 

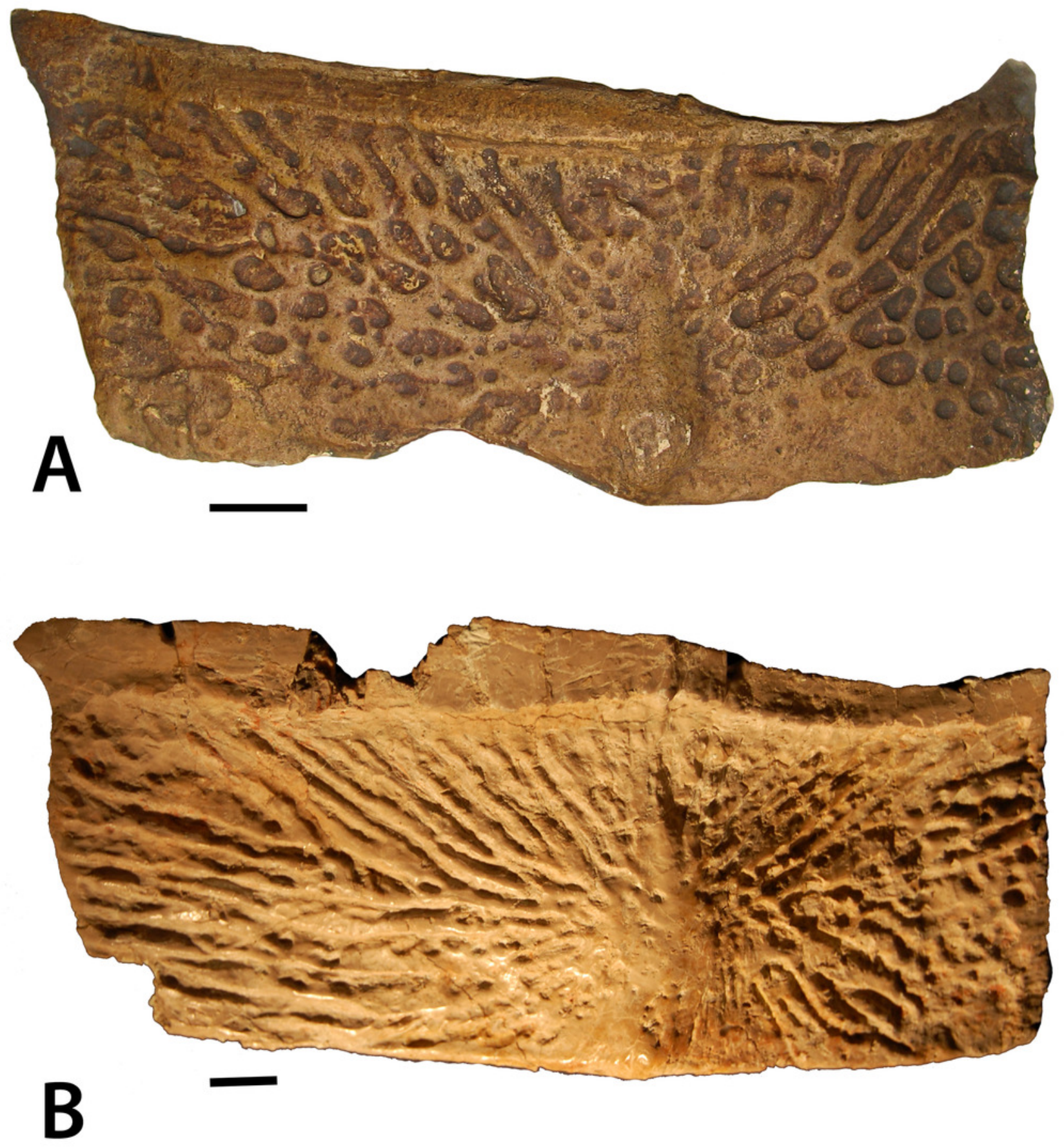


\section{Figure 10}

Alternate phylogenetic analysis of the Aetosauria.

Alternate phylogenetic hypothesis of the Aetosauria of Hoffman, Heckert, and Zanno (2018) with clade names and decay indices for each node.

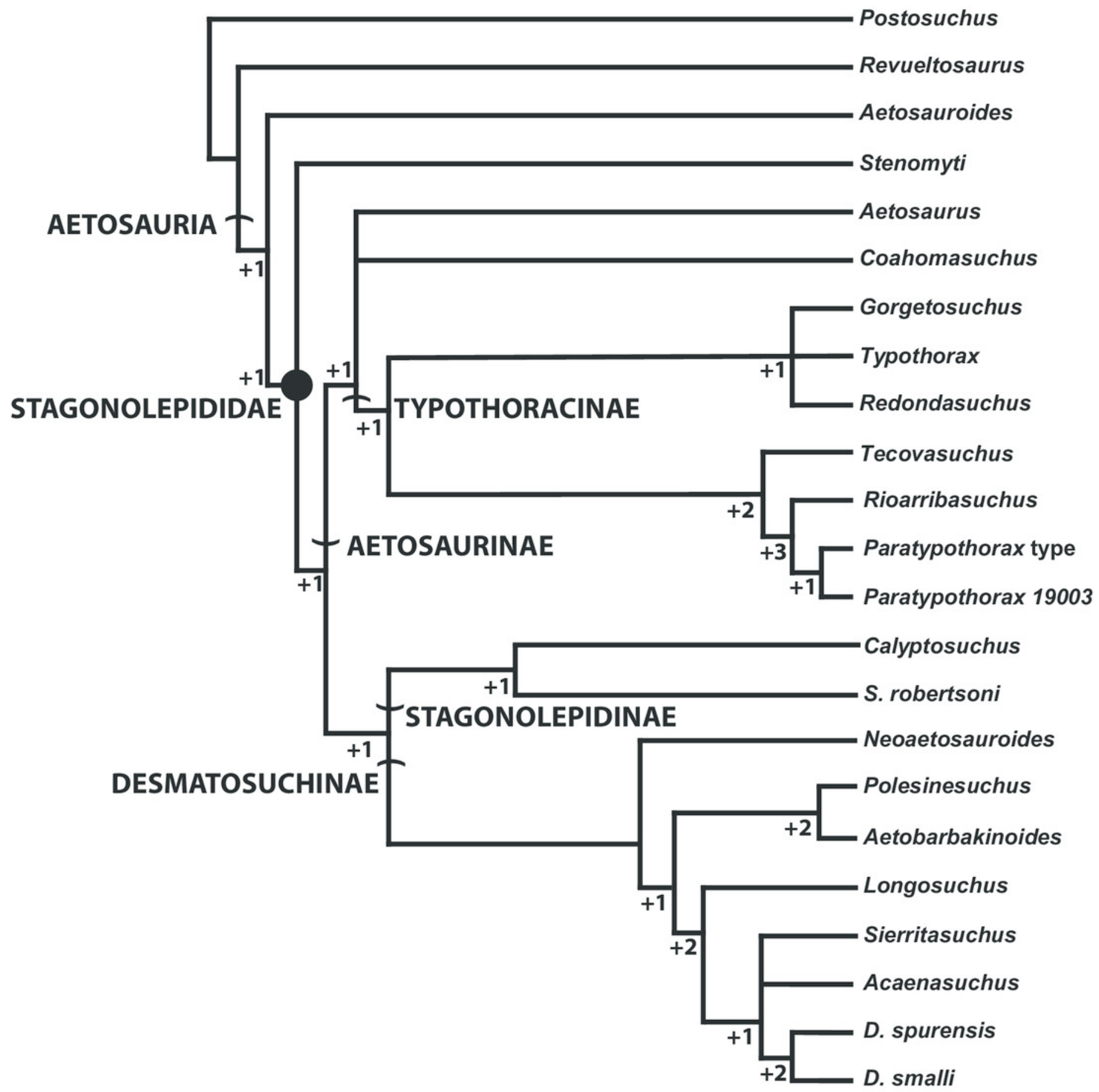


Figure 11

Holotype specimen of Stagonolepis robertsoni.

Cast of EM 27R, the holotype specimen of Stagonolepis robertsoni Agassiz 1844, a series of imbricated osteoderms from the ventral trunk region. 


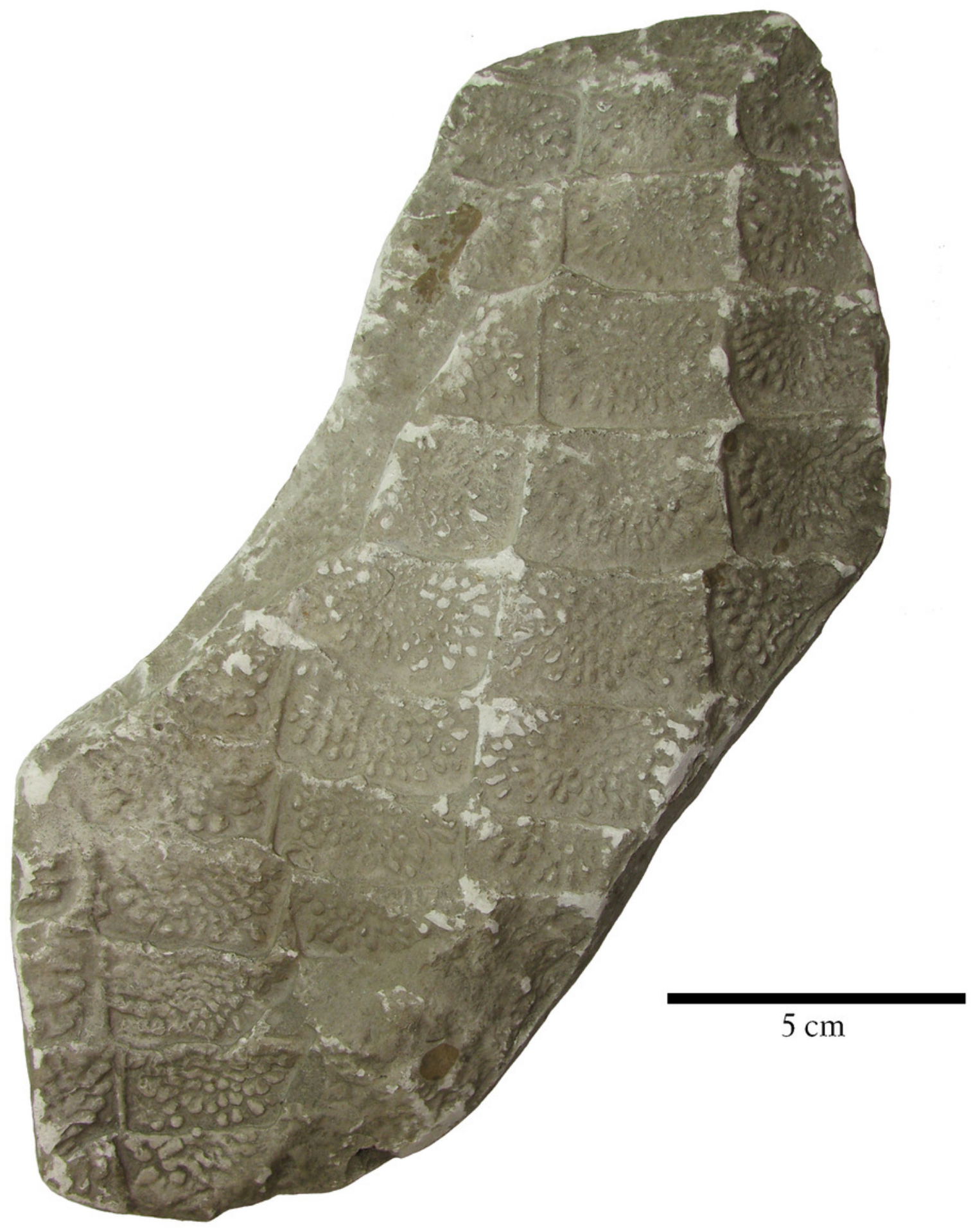

